\title{
SAKSKOSTNADER \\ I \\ SKATTE- OG AVGIFTSSAKER
}

\author{
Kandidatnummer: 603 \\ Leveringsfrist: 25 . november 2008
}

Til sammen 17624 ord 


\section{Innholdsfortegnelse}

1 INNLEDNING

$\begin{array}{lll}1.1 & \text { Tema og problemstilling } & 1\end{array}$

$\begin{array}{lll}1.2 & \text { Avgrensing } & 2\end{array}$

$\begin{array}{lll}1.3 & \text { Metode } & 4\end{array}$

$\underline{2}$ BAKGRUNNEN FOR DAGENS REGLER $\quad 7$

$\begin{array}{lll}2.1 & \text { Hvorfor har man regler om dekning av sakskostnader? } & 7\end{array}$

$2.2 \quad$ Historisk bakgrunn: Forvaltningsloven $\S 36$

$\begin{array}{lll}2.3 & \text { Historisk bakgrunn: Ligningsloven } § 9-11 & 13\end{array}$

2.4 Sammenlikning: Hvilke hensyn er det lagt vekt på? 15

$\underline{3}$ DE LEGE LATA: GJELDENDE RETT 19

3.1 Forvaltningsloven $\S 36 \quad 19$

3.1.1 Sakskostnader "skal" tilkjennes når et "vedtak" har blitt "endret til gunst for en part" 19

3.1.2 Kostnadene må være "vesentlige"

3.1.3 Kostnadene må ha "vært nødvendige for å få endret vedtaket” 23

3.1.4 Begrensningsregelen i første ledds siste del 27

3.1.5 Øvrige bestemmelser 29

3.2 Ligningsloven $§ 9-11 \quad 30$

3.2.1 De grunnleggende krav og $\varnothing$ vrige regler 30

3.2.2 Kostnadene må være "vesentlige" og "være pådratt med god grunn" 37

3.2.3 Særlig om urimelighetsvilkåret $\quad 41$

$\begin{array}{lll}3.3 & \text { Sammenlikning } & 53\end{array}$ 
4 DE LEGE FERENDA: BØR FORVALTNINGSLOVEN § 36 BRUKES I ALLE

6.1 Oversikt over forvaltningsoven med tilhørende relevante forarbeider, forskrifter og rundskriv m.v.

6.1.1 Relevante forarbeider til forvaltningsloven i kronologisk rekkefølge 61

6.1.2 Forskrift til forvaltningsloven $\quad 62$

$\begin{array}{lll}\text { 6.1.3 Rundskriv vedrørende forvaltningsloven } & 62\end{array}$

6.2 Oversikt over Ligningsloven med tilhørende relevante forarbeider, forskrifter og rundskriv m.v.

6.2.1 Ligningsloven 63

6.2.2 Relevante forarbeider til ligningsloven 63

6.2.3 Relevante forskrifter til ligningsloven 63

6.2.4 Relevante instrukser og retningslinjer til ligningsloven $\quad 64$

$\begin{array}{lll}6.3 & \text { Andre lover } & 65\end{array}$

6.4 Bøker, tidsskrifter og henvisninger til internett $\quad 66$

$\begin{array}{lll}6.5 & \text { Register over dommer } & 68\end{array}$

6.6 Register over saker fra Klagenemnda for merverdiavgift $\quad 69$

$\begin{array}{lll}\text { 6.7 } & \text { Register over Sivilombudsmannens uttalelser } & 70\end{array}$ 


\section{$1 \quad$ Innledning}

\subsection{Tema og problemstilling}

I forbindelse med forvaltningslovens ikrafttredelse ${ }^{1}$ understreket Justiskomiteen "at man...bør søke å unngå avvikelser fra forvaltningsloven som ikke er helt nødvendige på grunn av de særlige forhold i ligningsforvaltningen.”2

Jeg har valgt å se nærmere på et område hvor det har vært slike "avvikelser" helt siden ikrafttredelsen. Forvaltningslovens generelle bestemmelse i § $36^{3}$ om dekning av sakskostnader og særbestemmelsen vedrørende ligningsforvaltningen i ligningsloven § 9$11^{4}$ har hele tiden hatt svært ulik ordlyd. I neste hovedavsnitt vil jeg komme nærmere inn på at det fra lovgivers side også er lagt opp til en ganske ulik behandling i praksis etter de to bestemmelsene. Og lovendringer har bare gjort at forskjellene er blitt større.

Men det kan spørres om dagens praksis virkelig er så ulik som de formelle reglene skulle tilsi. Dette behandles i tredje hovedavsnitt.

Skatteetaten ble omorganisert 1. januar 2008. Det regionale skattekontoret fatter nå de vedtak både for skatt og merverdiavgift som gir grunnlag for å fremme krav om dekning av sakskostnader. Kravene vedrørende skattesakene skal behandles etter ligningslovens regel i § 9-11, mens krav vedrørende merverdiavgiftssaker skal behandles etter forvaltningslovens

\footnotetext{
${ }^{1}$ Lov om behandlingsmåten i forvaltningssaker av 10. februar 1967. Ved lov 54/1969 trådte den i kraft 1. januar 1970 .

${ }^{2}$ Innst.O. XXII (1968-1969), side 15 (punkt 13).

${ }^{3}$ Heretter stort sett forkortet til $\$ 36$.

${ }^{4}$ Lov om ligningsforvaltning av 13. juni 1980 nr. 24. Ved resolusjon nr. 1832/1983 trådte blant annet \$ 9-

$11 \mathrm{i}$ kraft 1. januar 1984. Heretter stort sett forkortet til $§ 9-11$.
} 
generelle regel i § 36. Det er også det regionale skattekontoret som behandler begge typer sakskostnadskrav i første instans. ${ }^{5}$

Sett fra den næringsdrivendes synsvinkel dreier det seg ofte om en og samme sak når Skatteetaten tar opp endringsspørsmål med betydning både for ligningen ${ }^{6} \mathrm{og}$ merverdiavgiften. ${ }^{7}$ Ikke sjelden vil sakene nemlig være basert på det samme faktiske grunnlag. Et enkelt eksempel kan illustrere situasjonen: For en næringsdrivende i dagligvarebransjen som mistenkes for å ha unnlatt å oppgi all sin omsetning til Skatteetaten, vil det normalt være det samme beløp, nemlig den ikke oppgitte omsetning det eventuelt skal beregnes både skatt (jf. skatteloven $§ \S 5-1$ og 5-30) og utgående merverdiavgift (merverdiavgiftsloven § 18) av. Den næringsdrivende har vanligvis brukt samme fullmektig i begge sakene, og ofte er det også de samme faktiske opplysninger som er relevante i begge sakene. Hvis han senere får medhold $i$ at han ikke har unndratt omsetning fra beskatning og avgiftsberegning, vil det nok stride mot den næringsdrivendes rettsoppfatning hvis dekningen av sakskostnader får ulikt utfall. Det er betimelig å spørre om forskjellene fortsatt er "helt nødvendige". Jeg vil gå nærmere inn på dette nedenfor under fjerde hovedavsnitt.

På bakgrunn av dette er min hovedproblemstilling om det fortsatt bør være en særskilt regel for behandling av sakskostnadssaker vedrørende ligningsavgjørelser, eller om disse sakene også bør behandles etter forvaltningslovens generelle regel i § 36 .

\subsection{Avgrensing}

Spørsmål om dekning av sakskostnader kan oppstå i ganske mange forskjellige situasjoner. Jeg har valgt å se nærmere på sakskostnader som kreves dekket etter at et forvaltningsorgan endrer et tidligere forvaltningsvedtak til gunst for en privat part. Med "forvaltningsvedtak" mener jeg slike vedtak som regnes som "enkeltvedtak" etter definisjonen i

\footnotetext{
${ }^{5}$ Lov om merverdiavgift av 19. juni $1969 \mathrm{nr} .66$ (merverdiavgiftsloven) § 57a og ligningsloven $\$ 9-11 \mathrm{nr} .1$.

${ }^{6}$ Skattekontorets kompetanse for ligningssaker følger av ligningsloven \$ 9-5 nr. 1 .

${ }^{7}$ Skattekontorets kompetanse for merverdiavgiftssaker følger av merverdiavgiftsloven $\S 56$.

${ }^{8}$ Lov om skatt av formue og inntekt av 26. mars $1999 \mathrm{nr} .14$.
} 
forvaltningsloven $\S 2$ første ledd bokstav b. Ligningsloven har ingen tilsvarende definisjon av vedtaksbegrepet. Etter ordlyden skal § 9-11 gjelde for 'ligningsavgjørelser'. Under avsnitt 3.2 vil jeg definere dette uttrykket nærmere.

Domstolenes dekning av sakskostnader har lenge vært en del av vårt rettssystem. Dekning i en slik situasjon går imidlertid utenfor rammene for min oppgave, og jeg avgrenser følgelig oppgaven mot tvistelovens (tidligere tvistemålslovens) regler om dekning av sakskostnader. ${ }^{9}$ Dette innbefatter også kostnader som er pådratt ved en forvaltningssak som senere kommer for retten. Nedenfor vil jeg likevel komme inn på grensen mellom de forvaltningsrettslige og prosessrettslige reglene. Ligningslovens særbestemmelse i $§ 9-11$ nr. 3 om dekning av sakskostnader hvor endring av ligningsavgjørelse følger av eller forutsettes i domsavgjørelse vil også bli omtalt.

Sakskostnader kan også søkes dekket etter alminnelige erstatningsrettslige regler. For en stor del innebærer dette andre vurderinger enn det som står sentralt i min oppgave, og jeg vil ikke gå nærmere inn på disse reglene. Praksis som illustrerer grensegangen mot erstatningsrettslig dekning vil imidlertid bli omtalt.

En part kan også oppnå dekning for sine sakskostnader etter reglene i rettshjelploven. ${ }^{10}$ Slik kostnadsdekning oppstår normalt i en situasjon hvor saken behandles rettslig. Dette ligger utenfor rammene av oppgaven, og jeg vil ikke gå nærmere inn på rettshjelplovens regelverk.

I visse tilfeller kan det gis inntektsfradrag ved skatteligningen for sakskostnader. Før lovfesting av regler som ga direkte dekning for sakskostnader, var dette den eneste muligheten for å få dekket noe av sakskostnadene uten å gå til sak mot forvaltningen. Fortsatt er inntektsfradrag et alternativ til direkte dekning av kostnadene. Jeg går ikke

\footnotetext{
${ }^{9}$ Lov om mekling og rettergang i sivile tvister av 17. juni 2005 nr. 90, kapittel 20. Før 1. januar 2008: Lov om rettergangsmåten for tvistemål av 13. august 1915 nr. 6, kapittel 13.

${ }^{10}$ Lov om fri rettshjelp av 13. juni $1980 \mathrm{nr} .35$.
} 
nærmere inn på disse reglene, ettersom de innebærer helt andre vurderinger enn det som følger av forvaltningsloven $\S 36$ og ligningsloven $\S 9-11 .{ }^{11}$

Endelig kan sakskostnader i en "sak som vesentlig er en tvist mellom parter", kreves dekket av en av de andre partene med hjemmel i forvaltningsloven $\S 36$ annet ledd. Jeg vil ikke gå nærmere inn på denne regelen, ettersom det er partenes innbyrdes forhold som står sentralt. Disse vurderingene faller utenfor rammen for oppgaven.

Jeg har valgt å ta for meg dekningsadgangen etter forvaltningsloven $\S 36$ første ledd med utgangspunkt i de dekningskravene som følger av merverdiavgiftssaker. Både ligningsforvaltningen og merverdiavgiftsforvaltningen er i stor grad er avhengig av å motta korrekte opplysninger fra den private part. Med hjemmel i merverdiavgiftsloven kapittel VIII og XII er det fastsatt svært detaljerte og strenge regler for den private partens ukrevede oppgaveplikt og plikt til å yte bistand ved Skatteetatens kontroller. Dette utgjør en parallell til skattyters plikter etter ligningslovens fjerde kapittel. Jeg finner det derfor interessant å sammenligne behandlingen av sakskostnadssakene på disse to områdene, ettersom de skal behandles etter to forskjellige forvaltningslover.

Det sentrale tema er selve dekningsadgangen. Øvrige regler vedrørende sakskostnadssakene vil også bli kommentert i den grad jeg anser det formålstjenelig.

\subsection{Metode}

En vurdering av den naturlige språklige forståelsen av ordlyden er det selvsagte utgangspunkt for tolkingen, men ofte vil uttrykkenes vaglet og/eller uklarhet sette klare begrensninger.

Lovforarbeidene gir et verdifullt innblikk i lovgivers intensjoner og avveiinger på det tidspunkt bestemmelsene ble vedtatt. I norsk rett blir det gjennomgående lagt stor vekt på

\footnotetext{
${ }^{11}$ Kostnadene kan være pådratt for å "erverve, vedlikeholde eller sikre skattepliktig inntekt" med fradragsrett etter skatteloven $\$ 6-1$ første ledd.
} 
uttalelser i lovbestemmelsenes forarbeider, og jeg vil i stor grad ta utgangspunkt i uttalelser fra forarbeidene som tolkingsmomenter ved vurderingen av gjeldende rett. ${ }^{12}$

Men gjeldende rett blir best fastlagt ved praktisk rettsanvendelse, først og fremst ved Høyesteretts praksis. Av betydning for denne oppgaven finnes det knapt slike avgjørelser, og heller ikke mye relevant rettspraksis fra lavere rettsinstanser. De relevante uttalelsene fra rettens side er systematisert i forhold til lovparagrafenes enkelte bestemmelser. Øvrig materiale som angitt nedenfor vil også bli systematisert i forhold til dette.

I mangel av rettspraksis, vil jeg i stor grad trekke fram relevant forvaltningspraksis som er allment tilgjengelig. Den generelle forvaltningsretten ses som nevnt i avsnitt $1.2 \mathrm{i}$ lys av praksis for merverdiavgiftssaker. Jeg vil derfor vise til avgjørelser fra Klagenemnda for merverdiavgiften. Fram til 1. januar 2008 er det kun denne ene nemnda som har avgjort saker på dette nivået (forvaltningsloven $§ 36$ tredje ledd). Her er avgjørelser fra de siste ti år tilgjengelig i fulltekst på Lovdatas nettsider. ${ }^{13}$

For ligningsavgjørelser og generelle redegjørelser vedrørende ligningspraksis vil jeg ta utgangspunkt i det som er tilgjengelig via Utvalget ${ }^{14} \mathrm{og}$ på internett via nettsidene til Lovdata og Rettsdata-skatterett. ${ }^{15}$ Ligningsavgjørelsene er vanligvis gjengitt i form av referater, og ikke som sitater. Først i Almvik og Kristiansen (2006) er det i noen større utstrekning sitert fra ligningsavgjørelser. Dette er tredje utgave av en serie bøker hvor ligningspraksis fra Sentralskattekontoret for storbedrifter (forkortet SFS) er beskrevet. De tidligere utgavene inneholder stort sett bare referater, og gir følgelig ikke førstehånds opplysning om hva ligingsorganet har ment. ${ }^{16}$ Jeg vil likevel henvise til bøkene, ettersom de gir verdifull informasjon om ligningspraksis.

\footnotetext{
${ }^{12}$ Eckhoff (Helgesen 2001) side 78-79 med eksempler.

${ }^{13}$ http://www.lovdata.no.

${ }^{14}$ Dommer, uttalelser m.v. i skattesaker (vanligvis forkortet Utvalget eller Utv.), utgitt siden 1918.

${ }^{15}$ Gyldendal rettsdata - skatterett (http:/ / www.rettsdata.no).

${ }^{16}$ Første utgave: Wilskow (red., 1997); andre utgave: Almvik m.fl. (2000).
} 
I en særstilling står Sivilombudsmannens uttalelser. Han har rett til å uttale seg om forhold innenfor forvaltningen, (jf. sivilombudsmannsloven $\S \S 4$ og 10). ${ }^{17}$ På de områdene jeg skal befatte meg med, er det ikke lovfestet noen direkte rett eller plikt til å følge ombudsmannens uttalelse. I ligningsloven forutsettes det imidlertid at spørsmål om endring av ligningsavgjørelse tas opp etter slik uttalelse. I § 9-6 nr. 5 bokstav d er det lovfestet et generelt unntak fra lovens frister for å ta opp endringsspørsmål (i nr. 1-4) for saker som tas opp etter Sivilombudsmannens uttalelse. For $\varnothing$ vrig er det allment anerkjent at uttalelsene ofte påvirker forvaltningens praksis. Jeg vil henvise til ombudsmannens uttalelser, fordi de svært ofte inneholder verdifulle vurderinger og utsagn som kan bidra til å fastlegge gjeldende praksis.

I begrenset omfang vil jeg også henvise til Skattedirektoratets Lignings-ABC. Boken gir i stor grad bare uttrykk for Skattedirektoratets syn på rettskildene, og gir normalt heller ingen henvisninger til dem. Som oppslagsverk over retts- og ligningspraksis vil boken derfor ha begrenset verdi. Men uttalelsene kan være med på å bekrefte en viss praksis på det aktuelle området.

Skattedirektoratet utgir også oppslagsverket "Merverdiavgiftshåndboken" (sist 5. utgave fra 2007) til veiledning i merverdiavgiftsspørsmål. Her finnes det imidlertid ikke henvisninger til sakskostnadsspørsmål for merverdiavgiftssakene. På dette området er man henvist til generell forvaltningsrettslig teori, nå først og fremst Woxholth (2006) og Bernt. ${ }^{18}$

Jeg henviser også til øvrig relevant juridisk teori og uttalelser, rundskriv med videre fra Justisdepartementet, Finansdepartementet og fra Skattedirektoratet. Dette kan også være med på å forklare praksis på sitt område.

\footnotetext{
${ }^{17}$ Lov om Stortingets ombudsmann for forvaltningen av 22. juni $1962 \mathrm{nr} .8$.
}

${ }_{18}$ Kommentarer til forvaltningsloven via Rettsdata-skatterett. 


\section{Bakgrunnen for dagens regler}

\subsection{Hvorfor har man regler om dekning av sakskostnader?}

Forvaltningsorganet skal selv i utgangspunktet sørge for at interessene til den private part blir ivaretatt. Dette må regnes som et grunnleggende forvaltningsrettslig prinsipp, og vil gjelde hele den offentlige forvaltning med mindre det er lovfestet uttrykkelige begrensninger. ${ }^{19}$

Etter forvaltningsloven har det enkelte forvaltningsorgan en lovfestet generell veiledningsplikt innenfor sitt saksområde etter forvaltningsloven $§ 11$. Når enkeltvedtak skal forberedes, har forvaltningsorganet i tillegg en omfattende utrednings- og informasjonsplikt i medhold av forvaltningsloven $§ 17$.

Av ulike årsaker kan det oppstå feil under sakens gang. Den private part kan selv ha forårsaket feilen. Han kan enten i vanvare eller med større eller mindre grad av skyld ha gitt mangelfulle eller feilaktige opplysninger om sakens faktum. Senere i sakens gang kan det være at han pådrar seg kostnader i et forsøk på å gjøre dette godt igjen.

Men forvaltningsorganet kan også gjøre feil. Sakens faktum kan bedømmes feil. Viktige detaljer ved sakens faktum eller rettsreglene kan overses eller feilbedømmes. Ved utpregede skjønnsmessige avgjørelser kan det være lett å overse eller feilbedømme faktorer som har betydning for behandlingen videre.

De fleste feil blir nok oppdaget før forvaltningsorganet treffer sitt vedtak, gjerne i forbindelse med varsel til den private part. Men av og til blir det ikke oppdaget noen feil.

\footnotetext{
${ }^{19}$ Se Frihagen (1981) side 58-59 og 78 flg. Frihagen kaller prinsippet "undersøkningsprinsippet" eller "offisialprinsippet".
} 
Og det er ikke sikkert at den private part selv har god nok innsikt i regelverket til verken å forstå hvordan han skal ta til motmæle mot forvaltningsorganet, eller til å vite hvilke midler han skal bruke for å vinne rett. Parten er ofte henvist til å søke kostbar bistand hos regnskapsfører, revisor og/eller advokat.

På denne måten pådrar den private part seg et økonomisk tap ved å få korrigert et feilaktig vedtak. Hvis det foreligger ansvarsgrunnlag, og de $\emptyset$ vrige erstatningsrettslige krav er oppfylt, kan parten fremme et ordinært erstatningsrettslig krav. Dette er imidlertid en tungvint løsning for både den privat part og forvaltningsorganet.

Til grunn for de erstatningsrettlige reglene ligger et grunnleggende reparasjonshensyn. Det tilsier at den erstatningsberettigede skal få sitt tap dekket. Dette hensynet har motivert lovgiver til å gi mer skjematiske, forvaltningsrettslige regler om dekning av sakskostnader. ${ }^{20}$ Disse reglene gir nærmere vilkår for dekningsretten, og andre regler om blant annet saksgangen for slike krav.

Forvaltningsrettens generelle regel om dekning av sakskostnader er lovfestet $\mathrm{i}$ forvaltningsloven $\S 36$. Etter merverdiavgiftsloven $\S 57$ a skal saker vedrørende merverdiavgiften behandles etter denne bestemmelsen.

For ligningsavgjørelser er situasjonen annerledes. Her er skattyter pålagt en omfattende opplysnings- og samarbeidsplikt i henhold til ligningslovens fjerde kapittel, herunder selvangivelsesplikten i $§ 4-2$. Det er følgelig skattyter som har hovedansvaret for å gi ligningsforvaltningen de opplysningene den trenger for å treffe korrekte ligningsavgjørelser. Likevel må også ligningsforvaltningen som nevnt ovenfor ivareta skattyters interesser generelt sett. Blant annet er varslingsplikten i forbindelse med endringssaker lovfestet i ligningsloven $§ 9-7$. Og med hjemmel i ligningsloven $\S 8$-1 plikter ligningsmyndighetene å foreta en helhetsbedømmelse basert på alle tilgjengelige momenter

${ }^{20}$ Se nærmere om blant annet reparasjonshensynet i avsnitt 2.4 . 
i saken. Derfor vil ligningsmyndighetene også ha ansvar for å komme fram til korrekte ligningsavgjørelser, men med større begrensninger enn i forvaltningen generelt.

Forvaltningslovens regler skal ifølge ligningsloven § 1-2 ikke gjelde for ligningsavgjørelser, jevnfør § 1-1. Ligningsloven har derfor en særskilt bestemmelse i § 911 om dekning av sakskostnader for ligningsavgjørelser. Som jeg vil beskrive i avsnitt 2.3, gir disse reglene en snevrere adgang til dekning enn forvaltningslovens regel.

\subsection{Historisk bakgrunn: Forvaltningsloven $\S 36$}

Som nevnt ovenfor i avsnitt 2.1, skal forvaltningsloven gjelde for saker som behandles etter merverdiavgiftsloven.

Den generelle regelen om dekning av sakskostnader i § 36 var ikke med i den opprinnelige loven av 10. februar 1967. Først i forbindelse med lovens ikrafttredelse 1. januar 1970 ble denne regelen lovfestet. ${ }^{21}$ Dekningsadgangen var ganske snever, ettersom den var forbeholdt "feil ved saksbehandlingen, avgjøringsgrunnlaget eller lovanvendelsen". Justiskomiteen presiserte i sine kommentarer til § 36 i Innst.O. XXII (1968-1969) side 13 at sakskostnader kunne dekkes "ved alle slags ugyldighetsgrunner, herunder også at vedtaket er i strid med forskrifter, at det er tatt utenforliggende eller ulovlige hensyn eller usaklig forskjellsbehandling.”

Av Innst.O. XXII (1968-1969) framgår det at forvaltningsloven ikke skulle gjelde ved behandlingen av ligningsavgjørelser. ${ }^{22}$ Med betydning for denne oppgaven gjaldt dette behandling av ligningsavgjørelser etter de daværende skattelovene ${ }^{2 s}$ og ligningsmyndighetenes arbeid med saker etter folketrygdloven ${ }^{24}$ "i samsvar med unntakene

\footnotetext{
${ }^{21}$ Ved lov 19. juni 1969 nr. 54 ble flere lovendringer og ikrafttredelsestidspunktet vedtatt.

${ }^{22}$ Punkt IV nr. 12, 13 (side 15), og 102 (side 32).

${ }^{23}$ Daværende skattelov for landet av 18. august $1911 \mathrm{nr} .8$ (landskatteloven) og skattelov for byene av 18. august $1911 \mathrm{nr} .9$ (byskatteloven). Avløst av ny lov om skatt av formue og inntekt (skatteloven) av 26. mars 1999 nr. 14.

${ }^{24}$ Lov om folketrygd av 17. juni 1966 nr. 12. Avløst av ny lov om folketrygd av 28. februar 1997 nr. 19.
} 
for saker etter skattelovene". ${ }^{55}$ Denne avgrensningen er videreført til § 1-4 i nåværende skattelov og til ligningsloven $\S 1-2 .{ }^{26}$

Lovbestemmelsen ble revidert, og dekningsadgangen vesentlig utvidet ved lov av 27. mai $1977 \mathrm{nr}$. 40. Inntil da hadde dekningsadgangen vist seg å være svært snever.

Sosialdepartementet uttalte i sitt høringsnotat i forbindelse med forslaget til revisjon at ”reglene er så strenge at det nesten er umulig å bli tilstått slik dekning.” ${ }_{27}$ På tross av dette mente blant annet Den Norske Advokatforening og Miljøverndepartementet at den svært snevre dekningsadgangen burde opprettholdes. ${ }^{28}$ Justisdepartementet foreslo likevel å innføre en presumsjonsregel for kostnadsdekning ved at uttrykket "kan" ble foreslått erstattet med "skal". I utgangspunktet skulle sakskostnadene dekkes, men adgangen ble moderert ved tilføyelsen "med mindre særlige forhold taler mot det." Rimeligheten av partens krav skulle følgelig vurderes, og dekningen skulle fortsatt være begrenset til "feil ved saksbehandlingen, avgjøringsgrunnlaget eller lovanvendelsen”. ${ }^{29}$

Rammen for kostnadsdekning ble også utvidet i samsvar med Justisdepartementets forslag. Uttrykket "særlige kostnader" ble endret til "vesentlige kostnader" for å presisere at også visse nødvendige kostnader som parten selv har båret uten å engasjere sakkyndig bistand, kan dekkes. ${ }^{30}$ I nytt annet ledd ble det lovfestet en regel om å gi dekning etter en rimelighetsvurdering også i andre særlige tilfeller, selv om parten ikke oppnådde å få vedtaket endret. Denne regelen ble igjen fjernet ved lov av 12. januar 1995 nr. 4. Forvaltningsorganets plikt til å informere parten om adgangen til å kreve sakskostnader dekket ble også lovfestet $\mathrm{i}$ et nytt femte ledd (nåværende fjerde ledd).

Justiskomiteen påpekte i Innst.O. nr. 50 (1976-77) side 7 at det fortsatt var "temmelig mange skranker for partenes krav på dekning av nødvendige utgifter til å få rettet uriktige

\footnotetext{
${ }^{25}$ Nåværende trygdeavgift og arbeidsgiveravgift, jf. folketrygdloven $\$ 24-4$, jf. $\$ 21-16$.

${ }^{26}$ Forvaltningsloven gjelder likevel for forskriftene etter ligningsloven.

27 Sitert i Ot.prp. nr. 3 (1976-77), side 100.

${ }^{28}$ Høringsuttalelsene er sitert i Ot.prp. nr. 3 (1976-77), side 100.

${ }^{29}$ Redegjørelse i Ot.prp. nr. 3 (1976-77), side 101-102.

${ }^{30}$ Redegjørelse i Ot.prp. nr. 3 (1976-77), side 102.
} 
avgjørelser." Komiteen endret lovens uttrykk i første ledd fra det opprinnelige "hel eller delvis dekning" til kun "dekning for vesentlige kostnader..." uten ytterligere begrunnelse. Loven ble endret i samsvar med forslagene fra Justisdepartementet og Justiskomiteen.

Daværende første og annet ledd i § 36 ble omarbeidet ved lov av 12. januar 1995 nr. 4. Regelen i tidligere annet ledd om dekning etter en rimelighetsvurdering ble ikke videreført. Dekningsadgangen etter nytt første ledd ble gjort helt generell, ved at det opprinnelige kriteriet om "feil ved saksbehandlingen, avgjøringsgrunnlaget, lovanvendelsen eller av en annen ugyldighetsgrunn" ble opphevet. Adgangen til dekning var ikke lenger knyttet opp til bestemte feiltyper, men ble likevel moderert noe ved at kostnader ikke skulle dekkes hvor "endringen skyldes partens eget forhold eller forhold utenfor partens og forvaltningens kontroll". ${ }^{31}$

Justisdepartementet ga i Ot.prp. nr. 75 (1993-1994), side 49 uttrykk for at det ikke ønsket å fremme noe forslag om endring av $\S 36$. Dette var i samsvar med tilbakemeldingen fra de fleste høringsinstansene. Departementet har følgelig ikke egne kommentarer til den vedtatte endringen.

Imidlertid hadde Advokatforeningen allerede i brev til departementet av 24. mai 1989 gitt uttrykk for at det burde innføres en regel om generell kostnadsdekning, ${ }^{32}$ Foreningen hadde tydeligvis endret standpunkt radikalt siden forrige høringsrunde før lovendringen i 1977, og uttalte nå: ’’Da det også stadig blir vanskeligere for menigmann å forholde seg til forvaltningsrettslige spørsmål, er det naturlig i større grad nå å ta de økonomiske konsekvensene av det. Regelgivningen har tiltatt betydelig i de senere år, og det er en kostnad ved dette at de som rammes av reglene ofte trenger fagkyndig bistand.” Og videre: "Med de strenge regler som gjelder for å oppnå dekning av rettshjelpsomkostninger i forvaltningssaker, virker det urimelig at det også settes skranker for offentlig dekning av

\footnotetext{
${ }^{31}$ Kort omtalt i Innst.O. nr. 4 (1994-1995), side 9-10.

${ }^{32}$ Omtalt og delvis sitert i Ot.prp. nr. 75 (1993-1994), side 48-49.
} 
omkostninger når forvaltningsvedtak blir endret." ${ }_{33}$ Advokatforeningen gjentok dette også i høringsrunden i forbindelse med departementets opprinnelige forslag til endring av $\S 36$. Etter Advokatforeningens mening burde parten få dekning for sine vesentlige sakskostnader ved endring til partens gunst bare med unntak for det tilfelle at "endringen skyldes endrede forhold utenfor både partenes og det offentliges kontroll." ${ }_{34}$

Justiskomiteens flertall mente imidlertid at $\S 36$ burde endres, og fremmet et forslag som stort sett var i samsvar med Advokatforeningens forslag. I Innst.O. nr. 4 (1994-1995), side 10 fant komiteens flertall det ganske enkelt "rimelig at parten tilkjennes dekning for vesentlige omkostninger som har vært nødvendige for å få endret vedtaket når et vedtak blir endret til gunst for en part, med mindre andre særlige forhold taler mot det." Flertallet mente likevel at det "ikke uten videre [var] rimelig" at saksomkostningene ble dekket i de tilfeller hvor endringen "skyldes partens egne forhold", eller "skyldes endrede forhold som ligger utenfor både forvaltningens og partens kontroll”. Det ble ikke gitt noen ytterligere begrunnelse. Komiteens mindretall påpekte imidlertid (side 10) at lovendringen innebar "at man i utgangspunktet innfører en alminnelig rett til å få dekket sakskostnader også i tilfeller hvor endringen av et vedtak skyldes overprøving av den skjønnsmessige vurderingen av hva vedtaket bør gå ut på.”

Loven ble endret i samsvar med forslaget fra Justiskomiteens flertall, og er ikke endret siden.

Det er gitt en omfattende omtale av lovendringen i Justisdepartementets "Rundskriv om endringer i forvaltningsloven m.v." G-37/95 av 23. mars 1995, under punkt 2.15 "Retten til å få dekket sakskostnader (§ 36)”. Departementets uttalelser er gitt etter lovendringen, og kan følgelig verken regnes som lovforarbeid eller 'etterarbeid fra lovgiverhold'. ${ }^{35}$

\footnotetext{
${ }^{33}$ Sitat i Ot.prp. nr. 75 (1993-1994), side 49.

${ }^{34}$ Omtalt og delvis sitert i Ot.prp. nr. 75 (1993-1994), side 52.

35 Jevnfør Eckhoff (Helgesen 2001) side 227 og 230-231.
} 


\subsection{Historisk bakgrunn: Ligningsloven § 9-11}

I forvaltningslovens forarbeider Innst.O. XXII (1968-1969) side 15 (nr. 13) sies det om forholdet til ligningsavgjørelser at "ligningslovgivningen for tiden er under revisjon og at det her er både mange og vanskelige spørsmål som ikke bør foregripes.” Som nevnt i avsnitt 1.1 "understreker [Justiskomiteen] at man ved revisjonen bør søke å unngå avvikelser fra forvaltningsloven som ikke er helt nødvendige på grunn av de særlige forhold i ligningsforvaltningen.” Jeg kan ikke se at forarbeidene til forvaltningsloven på noe senere tidspunkt berører forholdet til ligningslovens bestemmelser.

Etter uttrykkelige bestemmelser i skatteloven $§ 1-4$ og ligningsloven $§ 1-2$ skal forvaltningsloven ikke gjelde for ligningsavgjørelser. Som nevnt i avsnitt 1.2 har ikke ligningsloven noen generell definisjon av uttrykket "ligningsavgjørelse". I avsnitt 3.2 vil jeg beskrive nærmere hvordan uttrykket skal forstås i $§ 9-11$.

I Ot.prp. nr. 29 (1978-1979) side 119-121 vurderte Finansdepartementet inngående om det burde innføres regler om dekning av sakskostnader vedrørende ligningsavgjørelser etter samme mønster som daværende $\S 36$ i forvaltningsloven. Men departementet konkluderte på side 120 med at det var "lite hensiktsmessig” å tilpasse forvaltningsloven $\S 36$ slik at den kunne anvendes på ligningsavgjørelser. Til det skilte ligningsforvaltningen seg for mye ut fra $\varnothing v$ vig forvaltning. Etter forvaltningsloven $\S 17$ første ledd har forvaltningen plikt til å sørge for at saken er så godt opplyst som mulig før vedtak treffes. Når vedtak må endres på et område hvor disse reglene gjelder, vil det "lett kunne oppfattes som noe ekstraordinært, som naturlig reiser spørsmålet om det er gjort en feil som bør få konsekvenser for sakskostnadene.” (side 119) Departementet påpekte videre på side 119: ’Derimot er det en normal og nødvendig del av ligningssystemet at den ordinære ligning blir endret i betydelig omfang, og det samme gjelder i noen grad for de endringsvedtak som treffes av ligningsnemnda eller ligningskontoret."

Etter ligningslovens fjerde kapittel er det først og fremst skattyter selv som har plikt til å opplyse om sakens faktum. Departementet påpekte videre i Ot.prp. nr. 29 (1978-1979), side 
119 at "skattyternes opplysningsplikt medfører byrder som er ulikt fordelt", og var bekymret for at "noen skattytere slipper lettere fra sin opplysningsplikt enn andre de naturlig kan sammenligne seg med. Etter departementets mening (side 119) var det også fare for at mange "av de kostnader noen skattytere pådrar seg i klagesaker svarer til det andre har pådradd seg allerede for å oppfylle sin opplysningsplikt før ligningen. Med den tidsnød som hersker under ligningsarbeidet, vil det også være noe tilfeldig om en skattyter rekker å ta til gjenmæle mot et varsel, slik at han unngår å bli strengere lignet, eller om han vinner fram med sitt syn først etter klage. Departementet var også bekymret for at det ville være "ganske uoverkommelig å dekke sakskostnader i et slikt omfang at byrdene ved ligningsprosessen blir noenlunde likelig fordelt mellom skattyterne" (side 120). Og framfor alt var det "meget vanskelig å trekke en rimelig grense rundt en adgang til å dekke sakskostnader i ligningsforvaltningen.” (side 120) Etter departementets mening måtte det følgelig settes mange skranker for dekningsretten.

I Ot.prp. nr. 29 (1978-1979) side 120-121 foreslo departementet derfor egne regler for ligningsforvaltningen, hvor tre skjønnsmessige vilkår sto sentralt. Kostnadene måtte for det første regnes som "vesentlige", dernest måtte de være pådratt "med god grunn", og det måtte også være "urimelig" at skattyteren skulle dekke kostnadene selv. Til slutt måtte det også vurderes om skattyteren skulle gis hel eller delvis dekning for kostnadene. Under avsnitt 3.2 ser jeg nærmere på innholdet i disse kriteriene. Ligningsloven § 9-11 ble vedtatt ved lov av 13. juni $1980 \mathrm{nr} .24$ i samsvar med departementets forslag, og trådte i kraft 1. januar 1984. ${ }^{36}$

Ved lov av 10. april $1992 \mathrm{nr} .32$ ble det tilføyd et nytt siste punktum til nr. 3 (nåværende nr. 5 siste punktum). Ifølge Ot.prp. nr. 21 (1991-1992) side 52 skulle det fra nå av også dekkes kostnader ved å påklage avgjørelsen i kostnadsspørsmålet til overordnet klageinstans.

\footnotetext{
${ }^{36}$ Loven trådte i kraft gradvis over flere år. Ved resolusjon nr. 1832/1983 trådte § 9-11 i kraft 1. januar 1984 .
} 
I forbindelse med omorganiseringen av Skatteetaten 1. januar 2008 ble loven omredigert ved lov 15. desember 2006 nr. 77. ${ }^{37}$ Finansdepartementet fastsatte 16. november 2007 nr. 1258 forskrift om overgangsbestemmelser ved iverksettelse av ny organisering av ligningsmyndighetene 1. januar 2008. Departementet fastsatte også forskrift 23. november 2007 nr. 1285 om når skatteklagenemndas vedtak kan bringes inn for overprøving i Riksskattenemnda. Under avsnitt 3.2 beskrives dagens ordning nærmere. Etter anmodning fra Sivilombudsmannen ble dekningsadgangen også utvidet for tilfeller hvor skattyter senere får medhold ved domstolsavgjørelse. ${ }^{38}$

Flere av høringsinstansene under forberedelsen av lovendringen $\emptyset$ nsket at dekningsadgangen samtidig ble utvidet og vesentlig endret. ${ }^{39}$ Departementet fant imidlertid ikke grunn til å fremme ytterligere forslag om endringer.

\subsection{Sammenlikning: Hvilke hensyn er det lagt vekt på?}

I Ot.prp. nr. 3 (1976-77), side 101 sies det vedrørende forvaltningsloven $§ 36$ at "hovedbegrunnelsen for bestemmelsen er at det kan være rimelig at det offentlige dekker de utgifter som en person pådrar seg for å få endret uriktige forvaltningsvedtak", og videre at man er "kommet over i vurderinger som grenser opp til spørsmålet om det offentliges erstatningsansvar for uriktige forvaltningsavgjørelser”. Det må kunne sies at reglene bygger på samme grunnhensyn som erstatningsreglene, nemlig reparasjonshensynet. Gjennom disse reglene erkjenner forvaltningen innenfor visse rammer et ansvar for å erstatte det $\emptyset$ konomiske tap den private part har lidd for å vinne rett.

For å oppnå erstatningsrettslig dekning, stilles det blant annet krav til årsakssammenheng mellom den skadevoldende handlingen/unnlatelsen og tapet. Også etter § 36 oppstilles det krav til årsakssammenheng. Dagens regel i § 36 gir nærmest et objektivt ansvar for

\footnotetext{
${ }^{37}$ Forarbeider Ot.prp.nr. 1 (2006-2007), side 29-30.

${ }^{38}$ Ot.prp.nr. 1 (2006-2007), side 151-152. Bestemmelsen trådte i kraft straks med en ordlyd som samstemte med daværende nemndsstruktur. Omredigert ordlyd samstemmende med ny nemndsstruktur trådte i kraft 1. januar 2008.

39 Se kort omtale av Skattebetalerforeningens og Advokatforeningens forslag i Ot.prp.nr. 1 (2006-2007), side 29 .
} 
feilaktige vedtak, hvor begrensningsregelens bevisbyrde er lagt på forvaltningen. Dette gjør det betydelig lettere for den private part å vinne fram med sitt krav. Se avsnitt $3.1 \mathrm{om} \mathrm{det}$ nærmere innholdet i bestemmelsen.

Ved den opprinnelige lovfestingen er det tydelig at andre hensyn også veide tungt. I Ot.prp. nr. 38 (1964-1965) på side 21 sies det: "I visse tilfelle ville en slik regel kunne gi falske forhåpninger og føre til klage i utrengsmål.” Man engstet seg tydeligvis for hva lovfestning av generelle dekningsregler ville innebære, og fryktet at det ville komme en strøm av dekningskrav som både ville bli en belastning for forvaltningen og statsfinansene hvis reglene ikke ble strenge nok. Det er tydelig at effektivitetshensyn hadde en avgjørende betydning for at det ikke ble gitt generelle regler i den opprinnelige forvaltningsloven 10 . februar 1967, og at de reglene som ble vedtatt ved lov 19. juni 1969 nr. 54 var svært snevre.

Reglene om forvaltningens omfattende utrednings- og informasjonsplikt (se avsnitt 2.1) bidrar til at den private part skal kunne forutberegne sin rettsstilling, og at de helt grunnleggende hensyn til rettferdighet og likebehandling ivaretas. Justiskomiteen uttalte i Innst.O. nr. 50 (1976-77) på side 7 at dekningsregelen i $§ 36$ fortsatt satte ”temmelig mange skranker for partenes krav på dekning av nødvendige utgifter til å få rettet uriktige avgjørelser”. Jeg ser denne uttalelsen som et tegn på at den generelle holdningen var endret, og at hensynet til forutberegnelighet og rettferdighet borgerne imellom ble tillagt større vekt også i sakskostnadssakene. Loven ble først endret ved lov 27. mai 1977 nr. 40 da regelen om presumsjon for dekning av sakskostnader (første ledd) og om forvaltningens informasjonsplikt (nåværende fjerde ledd) ble lovfestet. Deretter ble dekningen gjort mer generell ved lov 12. januar $1995 \mathrm{nr} .4$.

Ved sistnevnte lovendring uttalte Justiskomiteens mindretall i Innst.O. nr. 50 (1976-77) side 10: "Rimelighetshensyn kan ikke tilsi at en rett til dekning av sakskostnader innføres i tilfeller hvor forvaltningen ikke har begått feil. Forslaget vil også ha omfattende økonomiske konsekvenser som vi pr. i dag ikke vet omfanget av.” Mindretallets 
vektlegging av effektivitetshensynet og dets forståelse av rettferdighetshensynet vant ikke fram. Det er tydelig at effektivitetshensynet ikke har hatt stor vekt ved utformingen av dagens regler. Forståelsen av rettferdighet borgerne imellom er også endret. Dagens regler tar større hensyn til at den private part skal kunne forutberegne sin rettsstilling.

Som nevnt under avsnitt 2.1, kan det godt tenkes at den private part selv er årsaken til det feilaktige vedtaket. Reglene har hele tiden avgrenset dekningsretten mot slike tilfeller. I Ot.prp. nr. 3 (1976-77) side 101 gir Justisdepartementet uttrykk for at man må unngå dekningsansvar "hvor dette er urimelig". Regelen må kunne sies å være motivert ut fra et grunnleggende rettferdighetshensyn. Den generelle rettsoppfatningen tilsier nok at det vil oppfattes som støtende hvis den private part som selv har bidratt til feilen får dekket kostnader ved senere å gi korrekte opplysninger, mens den som pådrar seg kostnader ved å gi de korrekte opplysningene til forvaltningen før noe vedtak er fattet, ikke får dekket sine kostnader.

Ligningsloven § 9-11 ble utformet i kjølvannet av forvaltningsloven $\S 36$. Bestemmelsen må derfor kunne sies å være motivert ut fra de samme grunnleggende hensyn som de opprinnelige reglene i § 36. I Ot.prp. nr. 29 (1978-1979) side 120 uttaler

Finansdepartementet at § 9-11 skulle "begrenses til en vesentlig mindre andel av antall endringer til gunst for skattyteren" enn det forvaltningsloven ga grunnlag for. § 9-11 er derfor knyttet opp til § 36 slik den lød før lovendring 12. januar 1995 nr. 4 ved at den skal gi snevrere dekning.

Videre i Ot.prp. nr. 29 (1978-1979) side 120 uttaler Finansdepartementet: "Hvis en stor andel av endringssakene skulle utvides til å omfatte spørsmålet om dekning av sakskostnader, ville det medføre en merbelastning på forvaltningen som ikke kan være forsvarlig til fortrengsel for det egentlige ligningsarbeid." Ligningslovens regel skulle være snevrere, motivert ut fra enda sterkere effektivitetshensyn. Den grunnleggende presumsjonen mot dekningsrett, de tre skjønnsmessige kriteriene som alle må være oppfylt for at det så 'skal' vurderes hel eller delvis dekning taler sitt tydelige språk om at det er 
effektivitetshensyn som først og fremst er ivaretatt. I motsetning til den nærmest objektive regel i dagens $\S 36$, oppstiller $\S 9-11$ flere kriterier for avveiing av skyld som grunnlag for dekning.

Den nevnte engstelsen for overbelastning av forvaltningens tidsmessige og økonomiske ressurser har derfor i enda større grad kommet til uttrykk ved utformingen av ligningslovens regler. I motsetning til forvaltningslovens regler er ligningslovens snevre kriterier fortsatt ikke endret. Jeg kan derfor ikke se at denne engstelsen har 'sluppet taket' i ligningsforvaltningen ennå. 


\section{De lege lata: Gjeldende rett}

\subsection{Forvaltningsloven $\S 36$}

Etter første ledd "skal" partens sakskostnader dekkes. Forutsetningen er likevel at et "vedtak blir endret til gunst" for parten. Det er også bare "vesentlige kostnader" som skal dekkes, og de må ha "vært nødvendige for å få endret vedtaket".

Fra den generelle dekningsadgangen gis det en begrensningsregel i første ledds siste del. Når "endringen skyldes partens eget forhold eller forhold utenfor partens og forvaltningens kontroll, eller andre særlige forhold taler mot det" skal sakskostnader ikke dekkes.

Nedenfor vil jeg redegjøre for gjeldende rett når det gjelder de enkelte kriterier i bestemmelsen.

\subsubsection{Sakskostnader "skal" tilkjennes når et "vedtak" har blitt "endret til gunst for en part"}

Ordlyden innebærer at det oppstilles en presumsjon for dekning av sakskostnader.

Dekningen er ikke begrenset til spesielle feiltyper eller situasjoner. Endret skjønnsutøvelse i endringsvedtaket gir derfor adgang til kostnadsdekning..$^{40}$ Det er ikke noe vilkår at forvaltningen skal ha gjort noen feil i forbindelse med det opprinnelige vedtaket. ${ }^{41}$

I samsvar med forvaltningslovens definisjon av uttrykket "part" i $\S 2$ første ledd bokstav e, må lovens uttrykk forstås slik at regelen gjelder den private part. Første ledd gjelder derfor det offentliges ansvar for den private parts sakskostnader.

\footnotetext{
${ }^{40}$ Se sitat fra Innst.O. nr. 4 (1994-1995) side 10 under avsnitt 2.2.

${ }^{41}$ Bernt (Rettsdata-skatterett) note 836 til forvaltningsloven.
} 
Begrepet "vedtak" må forstås likt med uttrykket "enkeltvedtak" $i$ forvaltningsloven $\S 2$ første ledd bokstav b, jevnfør bestemmelsen om lovens rekkevidde i $§ 3$ første ledd. ${ }^{42}$

I Sivilombudsmannens uttalelse referert i årsmeldingen for 1981, side 138 flg. drøftes selve vedtaksbegrepet i saker som gjelder merverdiavgiften. ${ }^{43}$ Uttalelsen synes å bygge på en forutsetning om at enhver ny fastsettelse av merverdiavgift utgjør et "vedtak" i lovens forstand. Jeg kan imidlertid ikke se at forholdet er berørt i senere praksis.

Ordlyden tilsier at et vedtak må ha blitt "endret". Dette forutsetter at et nytt (gunstig) vedtak som opphever det tidligere (ugunstige) vedtaket må ha blitt fattet. I Innst.O. nr. 4 (1994-1995) side 9-10 forutsettes dette blant annet ved opphevelsen av den tidligere regelen (daværende andre ledd) om dekning av sakskostnader ved en rimelighetsvurdering i situasjoner hvor vedtaket ikke var blitt endret (lov av 12. januar 1995 nr. 4).44

Både samme organs omgjøring av tidligere vedtak etter forvaltningsloven $\S 35 \mathrm{og}$ overordnet organs vedtak i klagesak etter $\S 28$ omfattes. ${ }^{45}$ Forutsetningsvis følger dette av første punktum i $§ 36$ tredje ledd hvor det framgår at sakskostnadsspørsmålet enten skal avgjøres av klageinstansen eller underinstansen, avhengig av hvilken instans som har fattet det gunstige vedtaket.

I praksis er betingelsen om nytt, gunstig vedtak fortolket strengt. Sivilombudsmannen henviste til slikt uttrykkelig krav i årsmeldingen for 2006, side 260.46 I klagesak 4833a/2004 avviser Klagenemnda for merverdiavgift krav hvor det ikke var fattet vedtak om endring. ${ }^{47}$

\footnotetext{
${ }^{42}$ Kapittel VI gjelder bare i forhold til enkeltvedtak. Bernt (Rettsdata-skatterett) note 833 til forvaltningsloven.

${ }^{43}$ Lovdata med referanse Somb-1981-67.

${ }^{44}$ Se også Woxholth 2006, side 551.

${ }_{45}$ Woxholth 2006, side 548; Bernt (Rettsdata-skatterett) note 834 til forvaltningsloven.

${ }^{46}$ Lovdata med referanse Somb-2006-66. Ombudsmannen avviste også dekning i analogi med § 36.

${ }^{47}$ Lovdata med referanse KMVA-2004-4833a. Klagenemnda for merverdiavgift heretter stort sett forkortet Klagenemnda.
} 
Det er antatt at dekningsadgang også foreligger når det fattes et vedtak som slår fast at et tidligere vedtak er en nullitet. ${ }^{48}$ Endringsvedtaket må imidlertid ikke bare midlertidig endre rettstilstanden, ved at førsteinstansen deretter fatter et nytt og gyldig vedtak som er likt det første (ugunstige) vedtaket. Denne forståelsen er lagt til grunn av Justisdepartementets lovavdeling i brev delvis sitert i Ot.prp. nr. 75 (1993-1994), side 50.49

Sivilombudsmannen avviser i årsmelding for 2000, side 189 ikke uttrykkelig en analogisk anvendelse av $\S 36$ i et tilfelle hvor det ikke var fattet nytt, gunstig vedtak. Den private part hadde her pådratt seg vesentlige sakskostnader ved å ta til motmæle mot et uriktig varsel fra fylkesskattekontorets side, som ble trukket tilbake uten at det ble fattet noe vedtak. Finansdepartementet hadde avgitt en uttalelse vedrørende saken som i realiteten ville innebære kostnadsdekning etter en analogisk anvendelse av $§ 36$ første ledd. ${ }^{50}$ Etter det jeg kan se, er Sivilombudsmannens uttalelse avgitt på et rent erstatningsrettslig grunnlag, men han anvender likevel "prinsippet" i forvaltningsloven $\S 36$ ved den erstatningsrettslige vurderingen. ${ }^{51}$

Klagenemnda har i klagesak 4427b/2001 innrømmet dekning i analogi med $\S 36$ for kostnader pådratt før opprinnelig (ugunstig) vedtak (se mer om dette i avsnitt 3.1.3.1). ${ }^{52}$ For øvrig er dekning i analogi med $§ 36$ avvist fra klagenemndas side så langt jeg kan se.

I praksis kreves det i utgangspunktet nytt (gunstig) vedtak. Ovenstående sak fra Sivilombudsmannen kan tyde på at forvaltningen ut over dette dekker kostnader på et erstatningsrettslig grunnlag. Likevel kan jeg ikke se at spørsmålet om analogisk anvendelse av $\S 36$ er avklart.

\footnotetext{
${ }^{48}$ Eckhoff (Smith 2003), sidene 286-287.

${ }^{49}$ Ot.prp.nr. 27 (1968-1969), side 45. Se Woxholth 2006, sidene 557-559 vedrørende flere forskjellige typetilfeller.

${ }_{50}$ Finansdepartementet anså ikke at erstatningsrettslig ansvarsgrunnlag forelå, ettersom skyldkravet ikke var oppfylt.

${ }^{51}$ Lovdata med referanse Somb-2000-50.

${ }_{52}$ Tilleggsinnstilling ikke tilgjengelig via Lovdata. Se sitat i Skattebetalerforeningens Avgiftsnytt 2/2003 side 21 1. Også omtalt i klagesak 4930a/2004 (Lovdata med referanse KMVA-2004-4930a).
} 


\subsubsection{Kostnadene må være "vesentlige"}

Uttrykket "vesentlige kostnader" vil naturlig diskvalifisere de mer ubetydelige kostnadene. Kostnadene må $\emptyset$ konomisk sett være tyngende for parten. I saker vedrørende merverdiavgiften tenker man typisk på kostnader som er pådratt ved å få bistand fra regnskapsfører, revisor og/eller advokat.

Det kan også spørres om det går noen generell nedre grense for 'vesentlighetskriteriet'. Klagenemnda for merverdiavgift har i mange tilfeller dekket forholdsvis lave beløp. I klagesak 5921b/2007 ble det dekket kostnader med kr 7 000, mens det i klagesak 5323b/2006 ${ }^{53}$ ble dekket kostnader på kun kr 3 292. Nemndas leder bemerket at dette er "for lite til at dette til vanlig vil være vesentlige kostnader i henhold til forvaltningsloven $\S$ 36". På grunn av spesielle forhold i saken ble det imidlertid enstemmig tilkjent dekning. I klagesak 5472/2006 ${ }^{54}$ anså nemnda at et beløp på kr 2096 ikke var 'vesentlig'. I praksis kan det følgelig ikke oppstilles noen nedre beløpsmessig grense, men en må ta sakens forhold i betraktning.

I Ot.prp. nr. 3 (1976-77), side 102 uttales det at "partenes tap ved tidsspille o.l. omfattes ikke av bestemmelsen." Det antas likevel at kostnader kan dekkes hvis parten lider et uunngåelig tap han kan dokumentere, for eksempel ved nødvendig fravær fra sitt arbeid som lønnstaker. .55

Klagenemnda for merverdiavgift ga i klagesak 5214b/2005 dekning for kostnader som parten hadde ved bruk av egne medarbeidere i tillegg til honorar til advokat. ${ }^{56}$ I klagesak 4790/2002 ble det derimot ikke gitt dekning for kostnader ved selskapets interne arbeid. ${ }^{57}$ Det må følgelig legges til grunn at det i praksis kan gis dekning for påviselige kostnader som trer i stedet for kostnader til ekstern bistand.

\footnotetext{
${ }^{53}$ Lovdata med referanse KMVA-2006-5323b.

${ }_{54}^{54}$ Lovdata med referanse KMVA-2006-5472.

${ }_{55}$ Bernt (Rettsdata-skatterett) note 838 til forvaltningsloven. Se også Woxholth 2006, side 560.

${ }^{56}$ Dissens 4-1 i nemnda. Dekning tilkjennes delvis etter erstatningsrettslig vurdering, og etter det jeg kan se ikke etter analogi med forvaltningsloven \$36. Lovdata med referanse KMVA-2005-5214b.

${ }_{57}$ Enstemmig avgjørelse. Lovdata med referanse KMVA-2002-4790b.
} 
Jeg vil også henvise til obiter dictum i Borgarting lagmannsretts dom 4. oktober 200758 hvor det sies at "i tvistemål for domstolene er det nå lovfestet at en part kan kreve rimelig godtgjøring for arbeid som ellers måtte ha vært utført av en prosessfullmektig, jf. tvisteloven $§ 20-5$ (1). Tilsvarende regel må antakelig få anvendelse ved fastsettelse av saksomkostninger etter ligningsloven $§ 9-11$. Hvis parten i sin helhet gjør arbeidet selv, kan omkostningene imidlertid ikke i noe fall overstige de omkostningene til en ekstern prosessfullmektig som det hadde vært adgang til å kreve dekket”. Det kan også spørres om det samme vil gjelde i forhold til forvaltningsloven $\S 36$. I utgangspunktet skulle en tro at det var like stor grunn til å gi dekning for verdien av eget arbeid etter denne bestemmelsen, men rettstilstanden er ikke klar.

\subsubsection{Kostnadene må ha "vært nødvendige for å få endret vedtaket"}

Ordlyden gir oss en viss pekepinn om hvor rammene for dette kriteriet går. Jeg behandler anvisningen om konkret vurdering først, og deretter kravet til årsakssammenheng.

\subsubsection{Saken skal vurderes konkret}

Det framgår tydelig av ordlyden at det skal foretas en konkret vurdering, nemlig nødvendigheten av de pådratte kostnadene i nettopp denne saken. Justisdepartementet omtaler nødvendighetskriteriet i sitt rundskriv G-37/95 av 23. mars 1995, i punkt 2.15 bokstav c. Når nødvendigheten av bistand skal vurderes, må det etter departementets vurdering "fortsatt legges vesentlig vekt på sakens vanskelighetsgrad og om saken har et komplisert faktum eller reiser kompliserte juridiske spørsmål. I saker hvor endringen skyldes endret skjønnsutøvelse, må det vurderes om bistanden har vært nødvendig for å vinne frem på dette grunnlaget.” Dette er for øvrig gjentakelser fra forarbeidene, Ot.prp. nr. 3 (1976-77), side 101 som departementet fortsatt mener er relevante.

\footnotetext{
${ }^{58}$ Utv. 2007, side 1459 flg.; se også Lovdata med referanse LB-2006-132699. Se nærmere avsnitt 3.2.2.1.
} 
I klagesak 4981/200459 anså Klagenemnda at pådratt advokathonorar var for høyt sett hen til sakens omfang og kompleksitet.

Det ligger ikke innenfor disse rammene å gi dekning for kostnader som kan henføres til tiden før det opprinnelige (ugunstige) vedtaket ble fattet, og heller ikke for tiden etter at det gunstige vedtak er fattet. Disse kostnadene kan ikke sies å ha vært "nødvendige" for å få det opprinnelige vedtaket endret. ${ }^{60}$ Se uttalelse fra Justisdepartementets lovavdeling 2185/84 E (punkt 3), ${ }^{61}$ og fra Klagenemndas praksis klagesak 5123b/200462 og klagesak 5235b/2005.63 Se også punkt 3.1.1 vedrørende eventuell analog anvendelse av § 36.

Det vil også være utenfor ordlydens grense å gi dekning for kostnader som gjelder spørsmål hvor parten ikke fikk medhold. Borgarting lagmannsrett bekrefter i dom 17. mars 1999 en slik forståelse: "Klagenemndas flertall har forstått dette slik at kostnader i forbindelse med klagepunkter som ikke har vunnet frem, heller ikke skal dekkes". Og videre: "I et slikt tilfelle vil det måtte bero på skjønn hvordan kostnadsdekningen skal fordeles”. Retten hadde heller intet å bemerke til nemndas utøvelse av skjønnet. Dommen gir ikke skriftlige referanser til nødvendighetskriteriet. Etter min mening vil den likevel være med på å underst $\varnothing t t e$ at det i forvaltningspraksis nektes dekning for den delen av sakskostnadene som etter en skjønnsmessig vurdering kan henføres til forhold hvor parten ikke har fått medhold. ${ }^{64}$

Mange av de sakskostnadssakene som er avgjort av Klagenemnda for merverdiavgift dreier seg om forståelsen av nødvendighetskriteriet. Avgjørelsene innebærer ofte en svært detaljert gjennomgang av de enkelte utgiftspostene og oppgavene over den konkrete

\footnotetext{
${ }^{59}$ Dissens 4-1 (dissenterende medlem ville ha fastsatt lavere dekning - i realiteten ved omgjøringssak). Se også Lovdata, referansenummer KMVA-2004-4981. Tilsvarende vurdering i klagesak 4933/2004 (KMVA2004-4933b).

60 Woxholth 2006, side 560 .

${ }^{61}$ Gjengitt i Lovavdelingens uttalelser (Matheson og Woxholth 1990) side 403.

${ }^{62}$ Lovdata med referanse KMVA-2004-5123b.

${ }^{63}$ Lovdata med referanse KMVA-2005-5235b.

${ }^{64}$ Lovdatas referanse LB-1998-674. Saken ble anket videre til Høyesterett (Rt. 2000 side 268), men påstand vedrørende sakskostnadsvedtaket ble trukket under ankeforhandlingen.
} 
bistanden. Hvis parten ikke har fått fullt medhold i merverdiavgiftssaken, anslås skjønnsmessig den andelen av kostnadene som gjelder de forhold han har fått medhold $\mathrm{i}$. Eksempelvis dekket klagenemnda i klagesak nr. 6111/2008 ${ }^{65}$ sakskostnader med kr 60000 av et totalt krav på kr 149960 etter en svært konkret vurdering av nødvendighetskriteriet. Så langt jeg kan se, er klagenemndas praksis generelt sett i samsvar med lagmannsrettens syn som angitt ovenfor. På dette punkt avviker vedtakene fra Klagenemnda sterkt fra tilsvarende vedtak i skattesaker, se avsnitt 3.2. Vedtak i skattesakene er ofte fundert i rent formelle betraktninger.

Kostnader ved å fremme krav om dekning av sakskostnader faller utenfor den naturlige forståelsen av bestemmelsens ordlyd. Slike kostnader har ikke vært "nødvendige" for å endre det opprinnelige (ugunstige) vedtaket, og kan derfor ikke dekkes. Derimot kan det dekkes kostnader som er pådratt ved å klage over et avslag i sakskostnadsspørsmålet når vedtaket i klagesaken er til gunst for den private part. Disse kostnadene har følgelig vist seg å være "nødvendige” i lovens forstand. Se Sivilombudsmannen i årsmeldingen for 2000, side $196^{66}$ og Klagenemnda i klagesak 4573/2002.67

Et særlig spørsmål blir om hvordan det stiller seg med kostnader ved behandling av andre organer i tiden før det gunstige vedtak fattes.

Sivilombudsmannen uttaler seg i årsmelding for 2000, punkt $5^{68} \mathrm{om}$ "sakskostnader pådratt i forbindelse med domstolsbehandling som var nødvendig for å få forvaltningen til å omgjøre et vedtak til gunst for den private parten." Ombudsmannen vurderer dette forholdet slik "at hele forvaltningssaken, medregnet eventuell domstolsbehandling som var nødvendig for å få endret vedtaket, må sees som et hele og vurderes samlet etter forvaltningsloven $\S 36$ ”. Når dekningsbeløpet skal fastsettes, må de kostnadene som eventuelt allerede er tilkjent av domstolen trekkes fra. Følgelig er tolkingen av $§ 36$ på

\footnotetext{
${ }^{65}$ Lovdata med referanse KMVA-2008-6111.

${ }^{66}$ Lovdata med referanse Somb-2000-53.

${ }^{67}$ Lovdata med referanse KMVA-2002-4573b.

${ }^{68}$ Lovdata med referanse Sombu-2000-5.
} 
dette punktet lik med rettstilstanden for skattesakene i og med den særlige regelen i § 9-11 nr. 3 .

I klagesak 4716bb/200769 dekket klagenemnda kostnader som omfattet både arbeid med å bringe saken inn for vurdering hos Sivilombudsmannen og arbeid overfor Finansdepartementet for å hindre at departementet omgjorde sak til ugunst for klageren. Klagenemnda avgjorde spørsmålet etter en vurdering av nødvendighetskriteriet. Se også klagesak 3927/2002.70

Det gis tydeligvis dekning for slike kostnader i praksis, det vil si kostnader som ikke allerede er dekket etter andre regler og i den grad de har ført til at det opprinnelige (ugunstige) forvaltningsvedtaket endres til gunst.

\subsubsection{Det må foreligge årsakssammenheng}

I lovens ordlyd ligger det en klar forutsetning om årsakssammenheng mellom (den gunstige) endringen og de pådratte kostnadene.

Uttrykket må også tolkes i samsvar med sammenhengen i forvaltningsloven. Det er naturlig å se kriteriet i lys av forvaltningsorganets grunnleggende utrednings- og informasjonsplikt etter $\S 17$. Det vil derfor ikke bli dekket kostnader når parten burde ha forstått at han kunne få tilstrekkelige opplysninger ved selv å kontakte forvaltningen, men han i stedet engasjerer advokat. Det antas at dette må ses fra partens synsvinkel. Lovens kriterium for dekning er derfor oppfylt hvis parten rent subjektivt sett hadde grunn til å tro at kostnadene var nødvendige. ${ }^{71}$ Se Sivilombudsmannen i årsmeldingen for 2000, fra side 24 med henvisning til uttalelse fra Justisdepartementets lovavdeling 26. juli 1989.72

\footnotetext{
${ }^{69}$ Lovdata med referanse KMVA-2007-4716bb.

${ }^{70}$ Lovdata med referanse KMVA-2002-3927.

${ }^{71}$ Eckhoff (Smith 2003), side 287; Woxholth 2006, side 561 og Bernt (Rettsdata-skatterett) note 837 til forvaltningsloven. Alle med videre henvisninger.

72 Sivilombudsmannens årsmelding for 2000, punkt 5. Se Lovdata med referanse Sombu-2000-5.
} 
I sak omtalt i Sivilombudsmannens årsmelding for 2006, side $249^{73}$ hadde den private part pådratt seg sakskostnader ved gjentatte purringer på Skattedirektoratets avgjørelse i merverdiavgiftssak. Klagenemnda kunne ikke se at kostnadene hadde tilstrekkelige tilknytning til endringsvedtaket, og avviste dekning etter sin forståelse av nødvendighetskriteriet. Sivilombudsmannen var uenig i klagenemndas tolking, og uttalte at nødvendighetskriteriet oppstiller et krav om årsakssammenheng mellom kostnaden og det gunstige endringsvedtaket. Dette innebærer et krav om at den sakkyndige bistanden skal ha vært nødvendig i seg selv. Men Sivilombudsmannen presiserte at det skal tas "utgangspunkt i partens subjektive oppfatning", og ikke i hva som rent objektivt framsto som nødvendig.

Saken viser at kravet til årsakssammenheng tydeligvis ikke kan praktiseres særlig strengt. Vurderingen skal som nevnt baseres på partens subjektive oppfatning av situasjonen, noe det kan være vanskelig for forvaltningen å få tilstrekkelig innsikt i. Ombudsmannens uttalelse viser likevel at nødvendighetskriteriet bør kunne avgrenses mot tilfeller hvor forvaltningsorganet etter objektivt konstaterbare kriterier klart har oppfylt sine plikter.

\subsubsection{Begrensningsregelen i første ledds siste del}

Kostnader skal ikke dekkes når "endringen skyldes partens eget forhold eller forhold utenfor partens og forvaltningens kontroll, eller andre særlige forhold taler mot det." I ordlyden brukes uttrykket "eller" mellom hvert av forholdene. En naturlig språklig tolking av ordlyden skulle da tilsi at det her oppstilles tre atskilte, alternative forhold som hver for seg gir grunnlag for å nekte dekning.

Regelen er ikke forstått slik i praksis. I sitt rundskriv G-37/95 under punkt 2.15 bokstav b (side 12) gir Justisdepartementet uttrykk for at "unntakene etter $\S 36$ første ledd kan uttrykkes slik at det er et vilkår for å få rett til dekning av sakskostnader at endringen skyldes forhold som ligger innenfor forvaltningens kontroll" (departementets utheving). Antitetisk fortolket vil det derfor foreligge dekningsadgang ved forhold som ligger innenfor

\footnotetext{
${ }^{73}$ Lovdata med referanse Somb-2006-63.
} 
forvaltningens kontroll. "Partens eget forhold" vil etter en slik tolking kun være et eksempel på forhold som ligger utenfor forvaltningens kontroll. Se også Woxholth ${ }^{74} \mathrm{og}$ Bernt. 75

Uttalelsene kan tas til inntekt for at det skal foretas en skjønnsmessig helhetsvurdering av eventuelle forhold som kan sies å være utenfor partens og forvaltningens kontroll. Helhetsvurderingens skjønnstema må etter det jeg kan se, være om det er rimelig å dekke sakskostnader i det foreliggende tilfellet. Etter en slik tolking ligger vurderingen nær opp til den urimelighetsvurderingen som følger av det tredje kriteriet etter § 9-11 nr. 4, men med motsatt fortegn.

I klagesak 4295/200176 reduserte Klagenemnda kostnadsdekningen "for partens eget forhold/andre særlige forhold som taler mot full dekning". Med utgangspunkt i uttalelse fra Justisdepartementet ser også nemnda det slik at "disse alternativene glir over i hverandre". Etter det jeg kan se, avgjorde klagenemnda dette forholdet på bakgrunn av en slik rimelighetsvurdering hvor de enkelte kostnadspostene ble gjennomgått svært nøye.

Ettersom det ikke finnes særlig praksis for merverdiavgiftssaker, er det vanskelig å si hva det konkret bør legges vekt på. Men det uttales i innstillingen (klagesak 4295/2001): "Utgangspunktet er imidlertid at en må være varsom med reduksjon." Denne uttalelsen sammen med det faktum at klagenemnda etter det jeg kan se, ikke i noe annet vedtak som er offentliggjort via Lovdata har brukt unntaksbestemmelsen, skulle tyde på at det ikke bør legges an til en streng fortolking av begrensningsregelen. ${ }^{77}$ Det må imidlertid være på det rene at det skal foretas en skjønnsmessig rimelighetsvurdering, basert på en avveiing mellom de forhold som ligger innenfor og de forhold som ligger utenfor forvaltningens kontroll.

\footnotetext{
${ }^{74}$ Woxholth 2006, side 554 (nr. 4)

${ }^{75}$ Bernt(Rettsdata-skatterett) note 841 , jf. note 840 til forvaltningsloven.

${ }^{76}$ Lovdata med referanse KMVA-2001-4295.

77 I én annen sak, klagesak 3998/2004 (lovdata med referanse KMVA-2004-3998b) innstilte Skattedirektoratet på avkortet dekning på grunn av partens eget forhold. En enstemmig nemnd gikk imot Skattedirektoratets innstilling på dette punktet.
} 


\subsection{5 Øvrige bestemmelser}

Det er parten selv som må ta initiativ for å kreve dekning innenfor en frist på tre uker fra mottak av melding om det gunstige vedtaket (tredje ledd). Det kan gis utsatt klagefrist og oppreisning ved overskredet klagefrist etter de generelle reglene i forvaltningsloven (tredje ledd henviser til $\S 29$ fjerde ledd og til § 31). Vedtak om dekning treffes av det forvaltningsorganet som har truffet den endelige avgjørelsen til gunst for parten. Parten kan påklage dekningsvedtaket uavhengig av vedtakets resultat.

Med virkning fra 1. januar 2008 gir ny $§ 57$ a i merverdiavgiftsloven særlige regler for behandling av sakskostnadskrav i merverdiavgiftssaker. ${ }^{78}$ Det regionale skattekontoret skal behandle og fatte vedtak i sakskostnadssaker etter sak i Klagenemnda for merverdiavgift. ${ }^{79}$ Skattekontorets vedtak påklages til Klagenemnda for merverdiavgift (annet ledd). Når det gjelder sakskostnadskrav i merverdiavgiftssaker bestemmes det i forvaltningsforskriften ${ }^{80} \S$ 34 tredje ledd bokstav b (jf. forvaltningsloven $\S 36$ tredje ledd fjerde punktum) at vedtak om sakskostnader som er truffet av Klagenemnda for merverdiavgift ikke kan påklages, heller ikke til Kongen (forskriftens første ledd).

I tillegg gis det i $§ 36$ tredje ledd regler om forvaltningsorganenes ansvar for de tilkjente sakskostnadene, ytterligere klageregler og forskriftshjemmel. I fjerde ledd er det lovfestet regler om hvilken informasjon som skal gis til parten. Hovedregelen er at parten skal gis informasjon om at han kan kreve å få dekket sakskostnader. Dette står i kontrast til skattesakene, hvor Finansdepartementets instruks 26. januar 1984 nr. 17 regulerer varsel til skattyter. Noen varslingsplikt framgår ikke av lov eller forskrift for disse sakene.

\footnotetext{
${ }^{78}$ Ved lov av 15. desember 2006 nr. 73. I kraft 1. januar 2008 ved resolusjon av 7. desember 2007 nr. 1371.

79 Tidligere fattet klagenemnda selv vedtak i disse sakene.

${ }^{80}$ Forskrift til forvaltningsloven av 15. desember $2006 \mathrm{nr} .1456$.
} 


\subsection{Ligningsloven $\S 9-11$}

Ligningslovens bestemmelse har, som nevnt under avsnitt 2.3 en annerledes oppbygning enn forvaltningslovens regel. De nærmere kriteriene for dekning finnes i nr. 4, ${ }^{81} \mathrm{hvor} \operatorname{det}$ framgår at sakskostnader "skal bare" dekkes når de oppfyller de etterfølgende tre kriteriene: De må være "vesentlige", videre må de "være pådratt med god grunn", og det må også være "urimelig om skattyteren måtte dekke dem selv."

Den grunnleggende forutsetning framgår av nr. 1, nemlig at ligningsavgjørelsen være 'endret til gunst' for skattyteren. I tillegg det vurderes "hel eller delvis dekning" for kostnadene.

Jeg vil først ta for meg de grunnleggende krav og lovens øvrige bestemmelser i den grad jeg finner det naturlig. Deretter vil jeg se nærmere på de tre kriteriene som framgår av lovens nr. 4.

\subsubsection{De grunnleggende krav og øvrige regler}

\subsubsection{Begrepet "ligningsavgjørelse"}

Dette er et flertydig begrep, hvor flere tolkinger kan være mulig ut fra ordlyden.

Sammenhengen i paragrafen viser oss at det bare er i de tilfellene hvor endringen er avgjort av skatteklagenemnda (nr. 1), Riksskattenemnda (nr. 2), eller eventuelt skattekontoret når den "følger av eller forutsettes i en domstolsavgjørelse" (nr. 3) at kostnadsdekning er aktuell. I disse tilfellene setter ligningslovens bestemmelser selv rammene for hvilke avgjørelser som kan være aktuelle. Ifølge dette vil avgjørelser som følge av klage med hjemmel i §§ 9-2 eller 9-3 jevnfør § 9-8 og avgjørelser etter ligningsmyndighetenes eget initiativ med hjemmel i § 9-5 jevnfør § 9-8 gi grunnlag for kostnadsdekning. Klage med hjemmel i § 9-3 vil derimot naturlig falle utenfor bestemmelsens virkeområde.

\footnotetext{
${ }^{81}$ I avsnitt 3.2 er henvisningene til ligningslovens paragrafer og til de enkelte nr. i $\$ 9-11$ når ikke annet er uttrykkelig angitt.
} 
Frostating lagmannsretts dom 18. desember $1995^{82}$ er med på å bekrefte dette. Retten anså at sakskostnader også kunne dekkes i et tilfelle hvor ligningsmyndighetene av eget tiltak omgjorde ligningsavgjørelse til gunst for skattyter.

Ligningslovens system for kompetanse i endringsspørsmål kan imidlertid by på visse utfordringer. I sak omtalt i Sivilombudsmannens årsmelding for 2004 side $235^{83}$ var skattyternes sak ikke fremmet for fylkesskattenemnda (skatteklagenemnda etter dagens system), slik at det gunstige vedtaket ville ha gitt grunnlag for kostnadsdekning. Derimot var saken henvist til ny behandling av ligningskontoret (nå skattekontoret) som realitetsbehandlet saken og fattet nytt gunstig vedtak i medhold av ligningsloven $\S 9-5 \mathrm{nr}$. 1 bokstav b, jf. § 9-8. Disse reglene gir nå skattekontoret initiativkompetanse og vedtaksmyndighet. Skattyterne hadde ikke klagerett til fylkesskattenemnda ${ }^{84}$, og framgangsmåten var formelt sett riktig når det i samsvar med regelen i $\S 9-5 \mathrm{nr}$. 1 bokstav b foreligger et nytt eller vesentlig endret faktum i saken. ${ }^{85}$ Det å benytte regelen er imidlertid uheldig når det gjelder sakskostnadsspørsmålet. Alternativt kan skattekontoret (daværende fylkesskattekontoret) legge saken fram for skatteklagenemnda ( $\$ 9-5 \mathrm{nr} .3$ ), eller anmode Skattedirektoratet om å fremme sak om overprøving for Riksskattenemnda (§ 9-5 nr. 5) alt etter hvordan saken står. Vedtak i skatteklagenemnda eller Riksskattenemnda gir som nevnt grunnlag for kostnadsdekning. Sivilombudsmannen uttaler seg ikke om denne delen av saksforholdet, men den nevnte praksis må kunne sies å være i dårlig harmoni med kravet til god forvaltningsskikk. Når ligningsmyndighetene har et reelt valg mellom to alternative framgangsmåter, bør en ikke velge den framgangsmåten som totalt sett er minst gunstig for skattyter. ${ }^{86}$

\footnotetext{
82 Utv. 1996 side 24; Lovdata med referanse LF-1995-72.

${ }^{83}$ Lovdata med referanse Somb-2004-61.

84. Vil nå oppstå ved spørsmål om overprøving av Riksskattenemnda.

${ }^{85}$ Harboe m.fl. (2005) note 5 til \$ 9-5 (side 395).

${ }^{86}$ Ifølge Sivilombudsmannens omtale ble sakskostnadene deretter dekket ut fra et erstatningsrettslig synspunkt.
} 


\subsubsection{Den opprinnelige ligningsavgjørelsen må være 'endret'.}

Dette kriteriet er klart oppfylt når skatteklagenemnda fatter et nytt vedtak som endrer skattyters beskatningsgrunnlag i forhold til skattekontorets vedtak.

Etter ordlyden vil det derimot ikke være oppfylt hvor skattyter har pådratt seg kostnader for å opprettholde det gunstige vedtaket når spørsmålet senere behandles av høyere instans, typisk ved ligningsmyndighetenes overprøving med hjemmel i § 9-5. Det nye vedtaket innebærer ingen 'endring' av den opprinnelige ligningsavgjørelsen, og slike kostnader kan følgelig ikke dekkes. Se Finansdepartementets uttalelse 9. oktober 1985.87

Kostnader ved å fremme sakskostnadskravet i første instans omfattes heller ikke av bestemmelsens ordlyd. Sivilombudsmannen ga uttrykk for denne oppfatningen i årsmeldingen for 1999 side 270. ${ }^{88}$ Han viste til Ot.prp. nr. 21 (1991-1992), side 52 hvor det sies at skattyteren tidligere ikke hadde "rett til å få dekket saksomkostninger som er pådratt i en saksomkostningsavgjørelse." Ved lov 10. april 1992 nr. 32 ble det imidlertid tilføyd en bestemmelse (nåværende nr. 5 siste punktum) som ga hjemmel for dekning av kostnader ved å utarbeide klage over sakskostnadsspørsmålet. Sivilombudsmannen mente at uttalelsen i forarbeidene og en antitetisk tolkning av den nye lovteksten støttet ligningsmyndighetenes syn. Ombudsmannen forsto det også slik at denne tolkningen var lagt til grunn i ligningspraksis siden ligningslovens vedtakelse. Overligningsnemnda for SFS nektet i sak 2001-403 dekning for kostnader ved å fremsette krav om sakskostnader, og henviste til uttalelse fra Sivilombudsmannen. ${ }^{89}$

Særbestemmelsen i nr. 5 første punktum gir som nevnt ovenfor hjemmel for dekning av kostnader ved å påklage sakskostnadsspørsmålet. Etter bestemmelsen har skattyter en ubetinget klagerett til skatteklagenemnda over sakskostnadsspørsmålet, på de samme vilkår som ved skattekontorets behandling i første instans (siste punktum). Se vedrørende

\footnotetext{
${ }^{87}$ Se Utv. 1985, side 674 (punkt 3).

${ }^{88}$ Lovdata med referanse Somb-1999-85.

${ }^{89}$ Almvik og Kristiansen (2006), side 1081.
} 
klageretten Sivilombudsmannens årsmelding for 2004, punkt 61. Det er ikke klagerett over verken skatteklagenemndas eller Riksskattenemndas avgjørelse i sakskostnadsspørsmålet (annet og tredje punktum).

Det kan også spørres om det vil foreligge dekningsadgang hvis det gunstige vedtaket senere blir omgjort. Etter dagens system vil det kunne skje hvis Riksskattenemnda overprøver skatteklagenemndas gunstige vedtak. Høyesterett traff avgjørelse vedrørende dette spørsmålet i dom 31. mai 2005, ${ }^{90}$ og uttalte at lovens ordlyd "oppstiller ikke noe vilkår om at vedtaket må bli opprettholdt ved eventuell overprøving av overordnet instans", og det vil i så fall "representere en innskrenkende tolking dersom det legges til grunn at bestemmelsen ikke kan anvendes" i dette tilfellet (avsnitt 64). Etter Høyesteretts mening "bør [man] være tilbakeholden med å tolke ligningsloven § 9-11 nr. 1 innskrenkende" (avsnitt 66). Reelle hensyn talte også mot innskrenkende tolking av loven (avsnitt 67). Høyesterett stadfestet enstemmig at tidligere nektingsvedtak skulle oppheves, og at dekning for sakskostnader i forbindelse med overligningsnemndas ${ }^{91}$ behandling skulle tilkjennes ved ny behandling.

Det skulle følgelig være godt grunnlag for å tolke dette kriteriet i samsvar med sin ordlyd.

\subsubsection{Endringen må være "til gunst for skattyteren"}

Sikker rett tilsier at skattyter ikke trenger å ha fått fullt medhold i sin sak. Det er tilstrekkelig at han har fått delvis medhold i sin påstand. ${ }^{92}$ Dette framgår uttrykkelig av Finansdepartementets veiledende retningslinjer av 26. januar 1984 nr. 16 (heretter omtalt som "Retningslinjene"), nr. 1 siste punktum.

\subsubsection{Det "skal" tilkjennes "hel eller delvis dekning"}

Dette er ikke noe eget kriterium som skal oppfylles. Uttrykket "skal" indikerer at det i hvert fall skal utbetales noe når en har kommet så langt i vurderingen. Jeg kan ikke se at

\footnotetext{
${ }^{90}$ Rt. 2005 side 692; se også Utv. 2005 side 715.

${ }^{91}$ Nå skatteklagenemnda.

92 Zimmer og Omholt 1993, side 103.
} 
lovteksten eller forarbeidene umiddelbart gir noen anvisning på hvordan en eventuell avkorting av dekningen skal foretas.

Men det eneste naturlige utgangspunkt på dette stadium i vurderingen bør være at skattyteren skal ha full dekning for de kostnadene som fortsatt anses som relevante. Retningslinjene punkt 5 første punktum gir også anvisning på dette. Men Finansdepartementet gir i annet punktum i punkt 5 anvisning på nok en vurdering av forholdsmessigheten: "Delvis dekning av sakskostnadene vil særlig være aktuelt der sakskostnadene virker urimelig høye, vurdert ut fra blant annet sakens art og forløp.”

Sivilombudsmannen henviser til Retningslinjene i brev gjengitt i Årsmeldingen for 1999 side 268.93 I utgangspunktet vil ligningsmyndighetene legge til grunn skattyters omkostningsoppgave. Skjønnsmessig reduksjon kan foretas når "kostnadsbeløpet [anses] urimelig høyt i forhold til det arbeid som er medgått eller vurderes å ha vært nødvendig". Hvis omkostningsoppgaven ikke finnes å gi "et betryggende faktisk grunnlag for å fastslå hvilke kostnader som reelt sett er pådratt i forbindelse med arbeidet for overligningsnemnda, vil de imidlertid - som enhver annen forvaltningsmyndighet - være henvist til å foreta en selvstendig bevisvurdering." Ombudsmannen bekrefter følgelig den vurdering av kostnadenes forholdsmessighet som framgår av de veiledende retningslinjene, og at det i visse tilfeller kan være grunnlag for å sette skattyters omkostningsoppgaver helt eller delvis til side.

Men forholdsmessigheten skal allerede være vurdert i sammenheng med kriteriet "pådratt med god grunn" (se avsnitt 3.2.2.2) og også ved vurdering av 'vesentlighetskriteriet' (se avsnitt 3.2.2.1). For meg framstår den skjønnsmessige vurderingen av forholdsmessigheten i nr. 1 bare som en gjentakelse/påminnelse på de anvisninger som er gitt tidligere i vurderingssyklusen. Jeg kan ikke se at denne vurderingen bør ha stor selvstendig betydning.

\footnotetext{
${ }^{93}$ Lovdata med referanse Somb-1999-84.
} 


\subsubsection{Noe om de øvrige saksbehandlingsreglene}

Skattyteren må selv fremme sitt krav overfor skattekontoret, som behandler og fatter vedtak i første instans. Fristen på tre uker regnes normalt fra partsbrev med utskrift av vedtak (nr. 1 og 5), eller melding om at saken skal behandles (nr. 2 og 3) kommer fram til skattyter. Skattyter skal varsles om dekningsadgangen etter Finansdepartementet instruks. ${ }^{94}$ Når sakskostnadsspørsmålet skal tas opp etter nr. 3 eller 4 må henholdsvis Skattedirektoratet og skattekontoret rette en henvendelse til skattyter i samsvar med prinsippet i § 9-7 for å få avklart sakskostnadsspørsmålet. Dette følger av Ot.prp. nr. 1 (2007-2008) side 30.

I Harboe m.fl. (2005) hevdes det på side 453: 'Det kan ikke være noe i veien for at den instans som treffer vedtaket av eget initiativ, forespør om kostnadsoppgave eller innrømmer sakskostnader skjønnsmessig." Den første delen av utsagnet har som nevnt ovenfor blitt regelen ved saker som behandles etter § 9-11 nr. 2 og 3. Sammenholdt med informasjonsplikten skulle det vel heller ikke være noe prinsipielt i veien for at skattekontoret går rett på sak og forespør om kostnadsoppgave. Den siste delen av utsagnet er det imidlertid vanskelig å være enig i. Det bør være grunn til å minne om at utgangspunktet i bestemmelsen er at det ikke skal gis dekning med mindre flere og svært detaljerte kriterier er oppfylt. Grunnen til dekning bør i alle tilfelle være tilstrekkelig sannsynliggjort, og skjønnsutøvelsen må i tilfelle gjelde hvor stor del av de totale kostnadene som kan henføres til dekningsberettigede forhold. Jeg kan ikke se at en slik 'saksbehandlingsregel' ${ }_{95}$ kan være i samsvar med hensynene bak bestemmelsen, jevnfør spesielt rettferdighetshensynet som vist ovenfor under avsnitt 2.4. Utsagnet kan etter min mening ikke utledes verken av en naturlig forståelse av bestemmelsens ordlyd eller dens sammenheng og system.

Skattekontoret og skatteklagenemnda avgjør sakskostnadsspørsmålet som hovedregel i en egen sak. Dette følger nå av at Riksskattenemnda (nr. 2) og skattekontoret når det "følger

\footnotetext{
${ }^{94}$ Instruks av 26. januar 1984 nr. 17. Den er ikke endret etter omredigeringen av $\$ 9-11$, men gjelder fortsatt med sin opprinnelige ordlyd.

${ }_{95}$ Utsagnet følger som andre setning under note 4 med overskriften ”saksbehandlingen”.
} 
av eller forutsettes i en domstolsavgjørelse” (nr. 3) positivt skal avgjøre sakskostnadsspørsmålet samtidig med den bakenforliggende saken. Motsetningsvis skal avgjørelse etter nr. 1 (ordinær avgjørelse av skattekontoret) og nr. 5 (skatteklagenemnda) avgjøres i en egen sak.

\subsubsection{Domstolenes prøvelsesrett}

Jeg kan ikke se at verken ordlyden eller uttalelser i forarbeidene tilfører momenter som sier noe om i hvilken grad ligningsmyndighetenes skjønnsutøvelse i sakskostnadssakene kan prøves av domstolene. Høyesterett har ikke tatt stilling til spørsmålet. ${ }^{96}$ Imidlertid har Borgarting lagmannsrett i dom 4. oktober 2007 uttalt vedrørende de tre kriteriene i nåværende nr. 4: "Samtlige kriterier kan prøves fullt ut av domstolene." 97 Frostating lagmannsrett uttalte derimot i dom 18. desember $1995^{98}$ at "når det gjelder selve skjønnsutøvelsen, den konkrete utmåling, har retten bare kompetanse til å undersøke om det er utvist såkalt myndighetsmisbruk.”

Zimmer og Omholt ga i 1993 uttrykk for at retten hadde full prøvelsesrett. ${ }^{99}$ Sett i lys av dette må det $\mathrm{i}$ beste fall være noe bastant når kommentarutgaven til ligningsloven ganske enkelt uttaler at "avgjørelsen vil ligge innen forvaltningens frie skjønn", og at det kun foreligger begrenset prøvelsesrett. ${ }^{100}{ }^{101}$ Dom i Oslo tingrett 13. november $2002^{102}$ henviser til denne usikkerheten: "Overligningsnemnda har etter det opplyste likevel ikke truffet saksomkostningsavgjørelse i saken. Den avgjørelsen antas å høre under forvaltningens frie skjønn, se Harboe m.fl. s. 492, (men motsatt hos Zimmer og Omholdt s. 106), og domstolsprøvingen av slikt vedtak er dermed begrenset”. Jeg kan ikke se at uttalelsen har hatt betydning for den konkrete avgjørelsen i saken, og den framstår følgelig som et obiter

\footnotetext{
${ }^{96}$ I dom inntatt i Rt. 2005 side 692 (Utv. 2005 side 715) tok Høyesterett kun stilling til rettsanvendelsen, det vil si eventuell innskrenkende tolking av \$ 9-11 nr. 1.

${ }_{97}$ Utv. 2007 side 1459 flg.; se også Lovdata med referanse LB-2006-132699.

${ }_{98}$ Utv. 1996 side 24; se også Lovdata med referanse LF-1995-72. På grunn av rettens manglende kompetanse ble saken avgjort etter alminnelige erstatningsrettslige prinsipper.

${ }_{99}$ Under punkt 7.4.4 på side 105-106, dog under en viss tvil.

${ }^{100}$ Harboe m.fl. (2005) note 5 til § 9-11 (side 454).

${ }^{101}$ Begrepene har imidlertid ikke noe fast og entydig innhold. Se vedrørende dette, og henvisning til rettspraksis i Eckhoff (Smith 2003) side 337-340.

${ }^{102}$ Lovdatas referanse TOSLO-2001-4697, ikke inntatt i Utv.
} 
dictum. Dommen er overprøvd av både lagmannsrett ${ }^{103}$ og Høyesterett, ${ }^{104}$ uten at spørsmålet er berørt nærmere. Men jeg konstaterer at det foreligger rettsavgjørelser i begge retninger, og rettstilstanden må kunne sies å være usikker.

\subsubsection{Kostnadene må være "vesentlige" og "være pådratt med god grunn"}

Det er alminnelig antatt at alle tre kriterier må være oppfylt for at kostnadsdekning skal være aktuelt. I dette avsnittet vil jeg ta for meg 'vesentlighetskriteriet' og kriteriet om at kostnadene skal "være pådratt med god grunn" i hvert sitt underavsnitt.

\subsubsection{Sakskostnadene må være "vesentlige"}

Det samme uttrykket er brukt i forvaltningsloven $\S 36$. Som nevnt ovenfor under avsnitt 3.1.2 må kostnadene $\varnothing$ konomisk sett være byrdefulle, og uttrykket vil naturlig avgrense dekningsretten mot $\varnothing$ konomisk sett ubetydelige kostnader.

Hva som er vesentlig for en skattyter trenger ikke å være det for en annen. Følgelig vil det være naturlig å forstå uttrykket slik at skattyters økonomiske stilling må ha betydning. Under punkt 2 i Retningslinjene framgår det at "skattyters økonomiske forhold" skal inngå i vurderingen av kriteriet.

Videre sies det i Retningslinjenes punkt 2 annet avsnitt: "Sakskostnadene må være påført ham i anledning endringssaken". Av dette forstås også at sakskostnadene må gjelde de spørsmål skattyteren har fått medhold i. Han kan ikke kreve dekket kostnader ved å utrede og ta til motmæle mot punkter hvor han ikke har fått noe medhold for sitt syn. Jeg kan ikke se at ordlyden i seg selv kan tas til inntekt for en slik tolking. Departementets utlegning i Retningslinjene må derfor innebære en ganske innskrenkende fortolking av uttrykket. Etter det jeg kan se, utgjør Retningslinjenes utsagn en klar henvisning til nødvendighetskriteriet etter § 36, hvor det både skal foretas en konkret vurdering av saken og hvor det må foreligge årsakssammenheng mellom kostnaden og endringen (se avsnitt 3.1.3).

\footnotetext{
${ }^{103}$ Utv. 2004 side 861; Lovdata med referanse LB-2003-9932.

${ }^{104}$ Rt. 2005 side 692; Utv. 2005 side 715.
} 
De tidlige forarbeidene til ligningsloven kan gi støtte til et slikt syn. Av Innst. III fra Ligningsforvaltningsutvalget av 1961, side 55 framgår uttrykkelig at kostnader ved forutgående behandling ikke skal kunne dekkes. Finansdepartementet henviser til dette utsagnet i uttalelse 9. oktober 1985.105

Dom i Borgarting lagmannsrett 4. oktober $2007^{106}$ kan også være med på å bekrefte en slik tolking. Etter det jeg kan se, bruker retten følgende uttalelse fra Riksskattenemndas vedtak 7. mars 1997 som hovedargument for å nekte dekning for sakskostnader: ’Det [er] i praksis lagt vekt på om kostnadene er pådratt helt eller delvis i tilknytning til det spørsmål skatteyteren har fått medhold i." ${ }_{107}$

Ytterligere en begrensning gis i Retningslinjene punkt 2 annet avsnitt. Kostnader som "skyldes at skattyteren ikke tidligere har oppfylt sin opplysningsplikt" skal ikke tas i betraktning ved vurderingen av om skattyteren har hatt vesentlige sakskostnader. Ordlyden vil heller ikke her gi noen indikasjon på at det skal foretas en slik vurdering. I vurderingen ser jeg en klar parallell til begrensningsregelen etter $\S 36$ hvor det blant annet skal tas hensyn til "partens eget forhold" (se avsnitt 3.1.4).

I praksis har det blitt tilkjent dekning med svært lave beløp. Frostating lagmannsrett tilkjente i dom 2. mars $1992^{108}$ dekning for sakskostnader med kr 3000.

Praksis ved SFS har avveket sterkt fra dette. I Almvik og Kristiansen (2006) ${ }^{109}$ henvises det til en sak hvor et sakskostnadsbeløp på kr 33100 ikke ble ansett å være vesentlig. Det er videre referert til de foregående års praksis hvor beløp av denne størrelsesorden i mange tilfeller ikke ble regnet som vesentlige.

\footnotetext{
${ }^{105}$ Inntatt i Utv. 1985 side 673-674 (punkt 1).

106 Utv. 2007 side 1459 flg., se også Lovdata med referanse LB-2006-132699.

${ }^{107}$ Omtalt og delvis sitert i Utv. 1997 side 416 (gjengitte utsagn er oppgitt å være et sitat fra vedtaket).

${ }^{108}$ Utv. 1992 side 548; ikke tilgjengelig via Lovdata.

109 Side 1082, sak 2001-405OLN.
} 
Som obiter dictum i Borgarting lagmannsretts dom 4. oktober $2007^{110}$ sies det at " $i$ tvistemål for domstolene er det nå lovfestet at en part kan kreve rimelig godtgjøring for arbeid som ellers måtte ha vært utført av en prosessfullmektig, jf. tvisteloven § 20-5 (1). Tilsvarende regel må antakelig få anvendelse ved fastsettelse av saksomkostninger etter ligningsloven § 9-11. Hvis parten i sin helhet gjør arbeidet selv, kan omkostningene imidlertid ikke i noe fall overstige de omkostningene til en ekstern prosessfullmektig som det hadde vært adgang til å kreve dekket”. I dette tilfellet var parten selv advokat. Saken ble ikke avgjort på dette grunnlaget, og rettstilstanden må kunne sies å være uviss. Men som nevnt kan det ikke utelukkes at tvistelovens regler får betydning for forståelsen av vesentlighetskriteriet. Det kan også spørres om eget arbeid fra parter som har andre profesjoner skal bedømmes på samme måte.

Ved SFS har det tydeligvis vært praksis å ta i betraktning kostnader for "egen juridisk ekspertise i konsernstaben" og når "morselskapet utfører juridiske tjenester for datterselskaper", se Wilskow (red., 1997) side 405. I sak 2001-402OLN fra overligningsnemnda for SFS er det dekket sakskostnader som er pådratt ved "egne ansattes arbeid". ${ }^{111}$

Likevel er det alminnelig antatt at kostnader ved forutgående behandling kan dekkes $i$ et par unntakstilfeller. I de tilfeller hvor Riksskattenemnda fatter et vedtak til skattyters gunst, kan de sakskostnadene som er påløpt både under skatteklagenemndas forutgående behandling og sakskostnadene for Riksskattenemnda dekkes. Skattedirektoratet gir uttrykk for dette i uttalelse 12. april 1985.112

Det vil også naturlig nok bli dekket sakskostnader for forutgående behandling når skattekontoret dekker sakskostnader ved endring "som følger eller forutsettes i en domstolsavgjørelse" (nr. 3). I Ot.prp. nr. 1 (2006-2007), side 151-152 presiseres det at forutgående sakskostnader kan dekkes innenfor rammen av de instanser som omfattes av

\footnotetext{
${ }_{110}^{10}$ Utv. 2007 side 1459 flg.; se også Lovdata med referanse LB-2006-132699.

${ }^{111}$ Almvik og Kristiansen (2006) sitat på side 1087.

${ }^{112}$ Inntatt i Utv. 1985 side 292. Dette må gjelde tilsvarende med ny nemndsstruktur fra 1. januar 2008.
} 
lovbestemmelsen. Nåværende system tilsier at sakskostnader pådratt ved skatteklagenemndas og eventuelt Riksskattenemndas behandling, og som ikke allerede er tilkjent av retten etter tvistelovens 20. kapittel kan dekkes etter denne bestemmelsen.

\subsubsection{Kostnadene må være "pådratt med god grunn"}

Ordlyden gir få holdepunkter for tolkingen. Den gir i seg selv ingen indikasjon på hva disse 'grunnene' skal måles opp mot, og hva som skal til for at grunnene kan regnes som 'gode'. En må derfor se etter tolkingsmomenter i sammenhengen og systemet i ligningsloven. I ligningsloven legges det stor vekt på skattyters plikt til å gi opplysninger om sakens faktum og til å samarbeide under sakens gang. Derfor vil det nok være naturlig å se uttrykket i lys av bestemmelsene om skattyters plikter i lovens kapittel 4.

Med visse begrensninger har skattyter også krav på veiledning fra skattekontorets side ( $\S \S$ 3-1 og 3-2). Sett i sammenheng med disse rettighetene og pliktene bør sakskostnadene være pådratt fordi skattyter ikke har god nok innsikt selv, og heller ikke kan få tilstrekkelig veiledning ved skattekontoret. Ot.prp. nr. 29 (1978-1979), side 120 peker uttrykkelig på dette forholdet. Retningslinjene utdyper dette i nr. 3 annet avsnitt, første punktum: "Av dette følger at det vanligvis må dreie seg om mer kompliserte forhold, der det ikke uten videre vil være klart for skattyteren hva rettsreglene går ut på, og hvilke faktiske forhold som derfor er relevante".

Kriteriet har derfor sitt motstykke i deler av forvaltningslovens nødvendighetskriterium i $\S$ 36. Som nevnt under punkt 3.2.2.1 har Finansdepartementets retningslinjer henført de viktigste delene av forvaltningslovens nødvendighetskriterium til ligningslovens vesentlighetskriterium. Tilbake står det å vurdere om den faglige bistanden har vært nødvendig i seg selv. Gode grunner skulle tilsi at en legger an samme synsvinkel som ved forvaltningslovens nødvendighetskriterium. Nødvendigheten av bistand må følgelig ses fra skattyters synsvinkel, og ikke ut fra de rent objektive forhold. Skattereglene er ofte kompliserte, og når skattyter først har søkt faglig bistand skal det nok litt til før ligningsmyndighetene avviser dekningskrav med begrunnelse i kriteriet om "god grunn". 
Jeg har ikke funnet noen tilfeller i offentlig tilgjengelig praksis hvor denne vurderingen har hatt selvstendig betydning.

Ifølge Retningslinjene punkt 3 annet avsnitt skal forholdsmessigheten også vurderes under dette kriteriet: "Det må dessuten være et rimelig forhold mellom de kostnader som skal dekkes og størrelsen av det spørsmål saken gjaldt.” Dette er en nærmest ordrett gjengivelse av uttalelse i Ot.prp. nr. 29 (1978-1979), side 120.

Frostating lagmannsrett avgjorde i dom 2. mars $1992^{113}$ dekningsspørsmålet i samsvar med Retningslinjenes anvisning, og tilkjente dekning bare for en mindre del av sakskostnadene fordi "det her er tale om en endring i skattyterens favør av meget begrenset omfang. De tilkjente omkostninger må stå $\mathrm{i}$ et visst forhold til tvistetemaets omfang." Jeg må konstatere at det ikke er store nyanser mellom reduksjon av kostnadsdekningen etter denne bestemmelsen, etter nåværende nr. 1 ("hel eller delvis dekning", se avsnitt 3.2.1.4) og etter vesentlighetskriteriet (se avsnitt 3.2.2.1).

\subsubsection{Særlig om urimelighetsvilkåret}

Finansdepartementet uttaler i Ot.prp. nr. 29 (1978-1979), side 120 og 121 at det tredje skjønnstemaet ville bli det vanskeligste å praktisere "noenlunde ensartet”. Jeg finner derfor grunn til å behandle dette mer inngående i et eget avnitt i min oppgave. Nedenfor vil jeg forsøke å fastlegge gjeldende rett nå nærmere 30 år etter departementets utsagn.

\subsubsection{Utgangspunktet for urimelighetsvurderingen}

Etter ordlyden skal sakskostnader bare tilkjennes "når det ville være urimelig om skattyteren måtte dekke dem selv." Uttrykket "urimelig" gir ikke mange språklige holdepunkter for hva som menes. Dette uttrykket har karakter av å være en rettslig standard hvor tolkingsmomentene må komme fra andre hold. Rent språklig er det heller ikke lett å se hvordan vurderingen av om det er "urimelig om skattyteren måtte dekke dem selv" skiller

\footnotetext{
${ }^{113}$ Utv. 1992 side 548. Ikke tilgjengelig via Lovdata.
} 
seg fra vurderingen av om kostnadene skal være "pådratt med god grunn". I utgangspunktet skulle man tro at det var 'rimelig' å dekke kostnader som var "pådratt med god grunn".

Borgarting lagmannsrett tolker tydeligvis lovens ordlyd i dom 4. oktober 2007, og uttaler følgende: ’Ligningsloven $§ 9-11$ oppstiller tre kriterier, alle av skjønnsmessig karakter... De to siste kriteriene glir langt på vei over i hverandre”. Retten siterer videre relevante avsnitt fra forarbeidene og Retningslinjene, men kommer ikke med ytterligere utsagn som kan bidra til forståelsen av kriteriene. ${ }^{114}$

I Gulating lagmannsretts dom 16. mars $2005^{115}$ omtales de tre kriteriene hver for seg, og det presiseres for hvert enkelt tilfelle at de er oppfylt. Noen nærmere beskrivelse gis heller ikke her.

Ut over dette kan jeg ikke se at urimelighetsbegrepet er vurdert rettslig. Jeg må konstatere at rettspraksis ikke har gitt noen nærmere definisjon av begrepet. De opprinnelige uttalelsene i forarbeidene vil derfor være høyst relevante ved tolkingen. I Ot.prp. nr. 29 (1978-1979) på side 120-121 er kun ett avsnitt viet til urimelighetskriteriet. Det innledes med det utsagn jeg har gjengitt innledningsvis i avsnitt 3.2.3.

Videre uttalte Finansdepartementet at "kravet vil være oppfylt først og fremst når ligningsmyndighetene har gjort en klar feil og det ikke har lykkes å få den rettet” etter det nåværende system ved klage til skattekontoret. Men det er ingen forutsetning at ligningsmyndighetene kan bebreides: "Selv om det ikke er noe å bebreide forvaltningen, kan avgjørelsen ved uhell eller misforståelser være blitt så klart uriktig at den må rettes”. Disse utsagnene må sammenholdes med det som sies avslutningsvis i samme avsnitt: "Dertil betyr det at skattyteren må ha vært utsatt for noe som ikke hører til dagens orden. Det behøver ikke være vilkårlighet eller klare feil, men det må være noe ekstraordinært som f.eks. et sammentreff av uheldige omstendigheter, slik at han har rimelig grunn til å

\footnotetext{
${ }_{114}$ Utv. 2007 side 1459 flg. (på side 1461) og Lovdata med referanse LB-2006-132699.

${ }_{115}$ Utv. 2005 side 741 flg. og Lovdata med referanse LG-2003-6419.
} 
føle seg forurettet over de kostnader han er blitt påført uten skyld.” Etter min mening må det viktigste i disse utsagnene være at det kan konstateres at det vedtaket som foreligger etter første klagerunde for skattekontoret fortsatt er feil. Jeg kan ikke se at det er grunn til å legge avgjørende vekt på de øvrige utsagnene, utover at de tjener som eksempler på hva som kan ha forårsaket feilen/feilene.

I praksis virker det som om de ovenstående utsagnene fra forarbeidene har vært gjenstand for en temmelig steng tolking. Ved vurderingen av urimelighetskriteriet er det tydeligvis tatt utgangspunkt i uttrykket "klar feil" . ${ }^{116}$ Finansdepartementet omtaler denne forståelsen i brev til Skattedirektoratet 6. juli 2007: "Forutsetningen for at sakskostnader skal tilkjennes er at ligningsmyndighetene har hatt en feil oppfatning av rettsreglene eller har bedømt faktum uriktig og dermed også kan bebreides for sakens tidligere løsning. Dette vil åpenbart være tilfelle der ligningsmyndighetene har gjort en "klar feil", men det kan ikke oppstilles som et vilkår at feilen må ha vært "klar". ${ }^{117}$ Sivilombudsmannen gir uttrykk for samme forståelse i uttalelse 25. august 2008, og sier også: ’Jeg forstår departementet videre slik at det ikke anses som en ufravikelig betingelse for å kreve saksomkostningene dekket, at myndighetene har begått en rettslig feil. Også i andre ekstraordinære tilfeller vil lovens vilkår kunne være oppfylt”. Han hadde intet å innvende til en slik forståelse. ${ }^{118}$

Omtalen av urimelighetskriteriet i Lignings-ABC er endret i samsvar med ovennevnte forståelse fra og med utgaven for 2007/08. Uttrykket "klar feil" brukes i det hele tatt ikke lenger i håndbokens beskrivelse, og det henvises direkte til Finansdepartementets uttalelse. 119

Retningslinjene oppstiller i begynnelsen av punkt 4 annet avsnitt nærmest en presumsjon mot dekning som jeg ikke finner noe godt grunnlag for i forarbeidene: "Når et vedtak får et materielt sett uriktig innhold, skyldes det i mange tilfelle at skattyteren selv ikke har

\footnotetext{
${ }^{116}$ Se eksempelvis saker fra SFS: Utv. 2002 side 193 (punkt 3.2.13). Samme utdrag gjengitt av Lovdata med referansene OLN-1997-405, OLN-1997-407, OLN-1997-408.

${ }_{117}^{11}$ Utv. 2007 side 1266 (på side 1268).

${ }^{118}$ Sak 2007/956.

119 Avsnitt 2.2.4 på side 381.
} 
presentert et fullstendig korrekt faktum. Når vedtaket i slike tilfelle deretter endres $i$ skatteyterens favør i en overordnet instans, vil det normalt ikke være urimelig at skattyteren selv bærer sine sakskostnader." Utsagnet gir etter min menig et fortegnet bilde av hva som må være utgangspunktet ved vurderingen. Verken lovens ordlyd eller mer eller mindre klare utsagn i forarbeidene gir grunnlag for å ha det utgangspunkt at skattyteren ”i mange tilfeller” ikke har oppfylt sine plikter. Vurderingen må være nøytral, og ikke for sentrert om å finne feil i skattyters opptreden. Omtalen i Lignings-ABC 2007/08 er mer nøytral, og oppstiller verken direkte eller indirekte noen presumsjon mot dekning i en slik situasjon. ${ }^{120}$

Det har vært omstridt om sakskostnadenes størrelse skal ha noe å si for urimelighetsvurderingen. ${ }^{121}$ Finansdepartementet uttaler i brev 6. juli 2007: "Størrelsen på sakskostnadene er ikke et moment i "urimelighetsvurderingen"". ${ }^{122}$ Uttalelsen gjentas ordrett i Lignings-ABC for 2007/08. ${ }^{123}$ Spørsmålet må derfor anses avklart i forvaltningspraksis.

Det ovenstående må anses å uttrykke dagens ligningsforvaltningspraksis. Etter det jeg kan se, er de med på å understøtte min påstand om at urimelighetsvurderingen ikke har noe annet utgangspunkt eller 'føringer' enn at ligningsavgjørelsen fortsatt er beheftet med feil.

\subsubsection{Gjennomføring av urimelighetsvurderingen}

Spørsmålet blir videre om hvordan urimelighetsvurderingen skal gjennomføres. Forarbeidene gir ikke noe klart svar på dette. Men som nevnt ovenfor gis det flere eksempler på klanderverdige forhold både hos den private part og hos forvaltningen.

\footnotetext{
120 Avsnitt 2.2.4 på side 381.

${ }^{121}$ Almvik og Kristiansen (2006), sitat fra sak 2001-405OLN på side 1082. Se også Utv. 2002 side 193 flg.(artikkelens punkt 3.2.13).

${ }_{122}$ Utv. 2007 side 1266 (på side 1268).

${ }^{123}$ Punkt 2.2.4 på side 381.
} 
Bergen byrett gjennomgikk i dom 26. september 1986 forhold på skattyters og ligningsmyndighetenes side svært inngående, og foretok til slutt en avveiing. ${ }^{124}$

Oslo tingrett foretar i dom 25. januar 2003 også en detaljert gjennomgang av sakens gang og vurderer klanderverdige forhold både på skattyters og ligningsmyndighetenes side. De klanderverdige forhold på begge sider blir deretter veid mot hverandre. ${ }^{125}$

Finansdepartementet gir i brev av 6. juli 2007 uttrykk for at det må "foretas en konkret helhetsvurdering, der både skattyterens og ligningsmyndighetenes forhold tas $\mathrm{i}$ betraktning." ${ }_{126}$ I sin uttalelse 25. august 2008 bekrefter Sivilombudsmannen denne oppfatningen, og henviser til departementets tilsvarende uttalelse i den aktuelle saken. ${ }^{127}$

Dette viser en entydig praksis over lang tid. Jeg legger til grunn at urimelighetsvurderingen skal foretas ved en konkret helhetsvurdering hvor forhold på skattyters og ligningsmyndighetens side vurderes og veies mot hverandre.

Spørsmålet blir videre om hvilke forhold som er relevante, etter hvilken norm forholdene skal vurderes, og hvem som kan klandres for at visse betingelser ikke er oppfylt. Jeg finner det mest naturlig å behandle disse spørsmålene under to forskjellige feilkategorier som etter min mening har hver sine karakteristiske trekk. Først feil ved det faktiske grunnlaget, og deretter feil ved bedømmelsen av faktum og rettsanvendelsen

De særlige spørsmål som oppstår når skjønnsmessige vurderinger er endret, behandles deretter i et eget underavsnitt.

\footnotetext{
${ }^{124}$ Utv. 1987 side 267 (på side 277-278); ikke tilgjengelig via Lovdata. Lagmannsretten (Utv. 1988, side 684) har ikke konkrete kommentarer til byrettens dom på dette punkt, men slutter seg ”i det vesentlige” til denne.

${ }^{125}$ Lovdatas referanse TOSLO-2003-12153, ikke inntatt i Utv.

126 Utv. 2007 side 1266.

127 Sak $2007 / 956$.
} 
Til slutt vil jeg se nærmere på urimelighetsvurderingen i saker hvor rettstilstanden er usikker. I slike saker står spesielt SFS overfor utfordringer knyttet til urimelighetskriteriet som etter min mening fortjener særskilt omtale.

\subsubsection{Feil ved det faktiske grunnlaget}

Det følger av ligningslovens system, og spesielt av lovens fjerde kapittel at det er skattyter som har hovedansvaret for å gi ligningsmyndighetene så gode opplysninger om sakens faktum til at de kan fatte riktige ligningsavgjørelser.

Finansdepartementet henviser til dette særtrekket ved ligningsforvaltningen i Ot.prp. nr. 29 (1978-1979) side 119: "Det er skattyterens plikt, gjennom selvangivelse og andre opplysninger å klarlegge alle faktiske forhold som knytter seg til hans økonomi, og å sannsynliggjøre de opplysninger har gir". Departementet presiserer: "Det [er] skattyteren som har hovedansvaret for å få fram opplysningene til hans egen ligning.”

På den annen side påpeker departementet i samme avsnitt: "Likevel er det helt normalt at ligningsforvaltningen trenger tilleggsopplysninger og nærmere avklaring på spesielle punkter. Som regel innhentes slikt under den forberedende behandling, før noen avgjørelse treffes". Departementet presiserer: "Ligningsforvaltningens hovedoppgave er å skaffe det best mulige faktiske grunnlag for ligningen".

Den nevnte helhetsvurderingen (se avsnitt 3.2.3.2) vil innebære at feil og mangler på begge sider må vurderes og veies opp mot hverandre. Jeg kan ikke se at forarbeidene ved sine uttalelser oppstiller noen presumsjon mot kostnadsdekning i de tilfeller der den feilaktige ligningsavgjørelsen kan føres tilbake til feil ved faktum. Selv om skattyter i utgangspunktet ikke har gitt tilstrekkelige opplysninger om et forhold, tolker jeg forarbeidenes uttalelser dit hen at det er ligningsmyndighetene som kan klandres hvis de ikke har etterspurt aktuell informasjon fra skattyters side.

Senere i Ot.prp. nr. 29 (1978-1979) side 120-121 oppfatter jeg departementets uttalelser slik at det oppstilles en norm som skattyters opptreden skal vurderes opp mot: 
"Rimelighetskravet betyr altså at skattyteren må ha gjort det som med rimelighet kan ventes av ham for å bistå med sakens opplysning". At uttrykket "rimelighet” brukes i denne sammenhengen, gir etter min mening en klar henvisning til at skattyterens personlige forutsetninger må vurderes konkret.

Samme sted (side 121) sies det også noe om normen for ligningsmyndighetene, men ikke like konkret: 'Dertil betyr det at skattyteren må ha vært utsatt for noe som ikke hører til dagens orden. Det behøver ikke være vilkårlighet eller klare feil, men det må være noe ekstraordinært som f.eks. et sammentreff av uheldige omstendigheter, slik at han har rimelig grunn til å føle seg forurettet over de kostnader han er blitt påført uten skyld.” Umiddelbart gir ikke dette stor veiledning. I utgangspunktet skulle jeg mene det var "ekstraordinært" at en ligningsavgjørelse fortsatt var feil etter at saken hadde vært behandlet av første klageinstans. Sett fra en slik synsvinkel gir uttalelsen grunn til å stille ganske høye krav til ligningsmyndighetenes opptreden under sakens gang.

Finansdepartementet henviser i sitt brev 6. juli 2007 til de ovennevnte uttalelsene fra forarbeidene. ${ }^{128}$ Sivilombudsmannen slutter seg til Finansdepartementets vurdering som han blant annet siterer følgende fra i uttalelse 25. august 2008: "Der skattyter ikke har gjort det som med rimelighet kan ventes av ham for å bidra til sakens opplysning, vil det normalt ikke være urimelig at hans selv bærer sine sakskostnader. ${ }^{129}$

Gulating lagmannsrett sluttet seg i dom 4. november $1988^{130}$ til Bergen byretts dom 26. september $1986^{131}$ hvor skattyter ble tilkjent full dekning for sine sakskostnader.

Avgjørende for saken var det at ligningsmyndighetene kunne klandres for at de ikke hadde forespurt om ytterligere opplysninger som kunne ha avklart forholdet.

\footnotetext{
128 Utv. 2007 side 1266.

129 Sitert i sak 2007/956. Uttalelsen framgår også av Finansdepartementets brev inntatt i Utv. 2007 side 1266.

130 Utv. 1988 side 684; ikke tilgjengelig via Lovdata.

${ }^{131}$ Utv. 1987 side 267 (på side 277-278); ikke tilgjengelig via Lovdata.
} 
Dom i Oslo tingrett 25. januar $2003^{132}$ kan også nevnes. Retten foretar en detaljert gjennomgang av sakens gang, og fastslår feil og klanderverdige forhold på begge sider. Etter rettens mening var skattyter mest å klandre, og fant at det ikke var urimelig om han måtte dekke sakskostnadene selv.

Fra ligningspraksis kan nevnes sak 1995-401OLN fra overligningsnemnda for SFS. Skattyteren hadde oppnådd et endret (gunstig) vedtak fordi det var lagt fram nye opplysninger om faktum. Sakskostnader ble ikke dekket fordi "nemnda la til grunn at opplysningene ikke var nye for selskapet, og at de kunne ha blitt inngitt på et tidligere stadium". ${ }^{133}$

Den anførte praksisen er entydig, og utgjør en bekreftelse på det syn som er angitt ovenfor. Det blir i praksis foretatt en helt konkret vurdering av de foreliggende klanderverdige forhold. De klanderverdige forhold på hver side veies deretter opp mot hverandre ved den endelige vurderingen av hvem som med rimelighet bør bære kostnadene.

Det finnes også eksempler på at skattyters forutsetninger i praksis er vurdert svært konkret. Sivilombudsmannen var enig i at Østfold fylkesskattenemnd hadde nektet å dekke sakskostnader, ${ }^{134}$ og påpekte i sin uttalelse 25. august 2008 at skattyteren "er en profesjonell aktør og må finne seg $\mathrm{i}$ at oppgaveplikten etter ligningsloven håndheves strengt". Ved dette tilfellet var tilleggsskatten frafalt, idet skattyters forhold ble ansett å være unnskyldelig ( $(10-3$ bokstav b). Spørsmålet var også om denne unnskyldeligheten 'smittet over' på urimelighetsvurderingen i sakskostnadsspørsmålet. Sivilombudsmannen uttalte at selv om den aktuelle unnlatelsen ble ansett som unnskyldelig for tilleggsskattespørsmålet, var det fortsatt "et relevant hensyn ved rimelighetsvurderingen". ${ }^{135}$ Det må legges til grunn at det skal foretas en helt selvstendig vurdering av de forhold som har betydning ved urimelighetsvurderingen.

\footnotetext{
132 Lovdatas referanse TOSLO-2003-12153, ikke inntatt i Utv.

${ }^{133}$ Almvik m.fl. (2000) side 619.

${ }^{134}$ Utv. 2007 side 244 (referert under punkt 3.2.13).

${ }^{135}$ Sak $2007 / 956$.
} 


\subsubsection{Feil ved bedømmelsen av faktum og rettsanvendelsen}

I Ot.prp. nr. 29 (1978-1979) side 120 påpekes at "avgjørelsen ved uhell eller misforståelser [kan ha] blitt så klart uriktig at den må rettes", men gir for øvrig ingen beskrivelse av slike feil. Retningslinjene punkt 4 annet avsnitt nevner at rett til dekning foreligger når ligningsmyndighetene "bedømmer [de faktiske forhold] uriktig".

Finansdepartementet konkluderer i brev 6. juli 2007 med at "det i utgangspunktet vil være urimelig om skattyter må dekke sakskostnadene når saken utelukkende har dreid seg om rettslige vurderinger". Dette under forutsetning av at "ligningsmyndighetene har hatt en feil oppfatning av rettsreglene eller har bedømt faktum uriktig og dermed også kan bebreides for sakens tidligere løsning”. ${ }^{136}$ Dette framgår også av Lignings-ABC 2007/08.137

I sak 2001-402OLN tilkjente overligningsnemnda for SFS full dekning for sakskostnader, ettersom sakens faktum "i all hovedsak [var] fastlagt", men var "blitt bedømt forskjellig" ved ligningsnemndas forutgående behandling. ${ }^{138}$

Jeg kan ikke se at det foreligger rettspraksis hvor det tas direkte stilling til slike feil. Uttalelsene vedrørende ligningspraksis er imidlertid entydige. Det ser ut til å kunne oppstilles en klar regel om at ligningsmyndighetene når de фvrige krav er oppfylt, plikter å dekke sakskostnader når feilen kan henføres til bedømmelsen av faktum eller den videre rettsanvendelsen. Ligningsmyndighetene har hånd om hele denne prosessen, og må ta følgene av de feil som oppstår. Avgjørende må være om ligningsmyndighetene faktisk hadde til sin rådighet korrekte opplysninger om faktum (se avsnitt 3.2.3.3 vedrørende ukorrekt faktum).

SFS har tidligere ikke gitt dekning for sakskostnader som er pådratt i saker hvor rettstilstanden har vært usikker. ${ }^{139}$ Disse sakene vil nødvendigvis dreie seg om "rettslige

\footnotetext{
${ }^{136}$ Utv. 2007 side 1266 (på side 1268).

137 Punkt 2.2.4 på side 381.

${ }^{138}$ Almvik og Kristiansen (2006), sitat og omtale på side 1086-1087.
} 
vurderinger, og må derfor omfattes av Finansdepartementets uttalelse i brev 6. juli 2007.140 Departementet gir klart uttrykk for at § 9-11 hjemler dekningsrett for slike saker. Jeg kan likevel ikke se at spørsmålet er vurdert rettslig, og konstaterer at rettstilstanden må kunne sies å være usikker.

\subsubsection{Endring av skjønnsmessige vurderinger}

Det kan spørres om endring av ligningsavgjørelser som skyldes skjønnsutøvelsen står i noen særstilling i forhold til andre endringsårsaker.

I Ot.prp. nr. 29 (1978-1979) side 119 nevner Finansdepartementet tilfeller hvor endringen skyldes "bare en viss ulikhet i vurderingen innenfor rammen av en fullt forsvarlig skjønnsutøvelse. Også bevisvurderingen må ofte bli skjønnsmessig, fordi ligningsmyndighetene ikke har fullgod viten om de faktiske forhold. Da må de legge til grunn det som er mest sannsynlig etter det som foreligger”. Jeg kan ikke se at departementet kommer med ytterligere utsagn som gir noen anvisning på hvordan forvaltningen bør forholde seg til slike tilfeller ved urimelighetsvurderingen.

Likevel finner jeg god grunn til å sammenholde dette med uttalelsen samme sted på side 120, hvor departementet uttaler at sakskostnadssakene på ligningsforvaltningens område må "begrenses til en vesentlig mindre andel av antall endringer til gunst for skattyteren”. På dette punkt er $\S 9-11$ knyttet opp til § 36 slik den lød før lovendring 12. januar 1995 nr. 4 (se avsnitt 2.4). § 36 ga på dette tidspunktet ikke hjemmel for å dekke sakskostnader ved endring av skjønnsmessige avgjørelser (se avsnitt 2.2). Ettersom ligningslovens regel helt tydelig skulle være snevrere enn forvaltningslovens regel, kan det hevdes at ligningsloven heller ikke gir hjemmel for å dekke slike sakskostnader.

I praksis vil nok mange saker kunne avgjøres på annet grunnlag. Dette vil være tilfellet hvor skjønnsutøvelsen for så vidt er endret, men hvor skattyter ikke har gjort det en med

\footnotetext{
139 Almvik og Kristiansen (2006) side 1083-1084 (sak 1995-402OLN), og generelle uttalelser side 10871088.

${ }^{140}$ Utv. 2007 side 1266.
} 
rimelighet kan forvente, eller ligningsmyndighetene har oversett eller feilbedømt enten faktumopplysninger eller forhold vedrørende rettsanvendelsen. Her må de feil og klanderverdige forhold som foreligger, bedømmes på samme måte som nevnt ovenfor under avsnittene 3.2.3.3 og 3.2.3.4. Det må være dette Finansdepartementet henviser til når det i brev til Sivilombudsmannen gir uttrykk for at det skal foretas en "konkret helhetsvurdering" av både skattyters og ligningsmyndighetenes forhold også i de tilfeller hvor skjønnsutøvelsen endres. Ombudsmannen refererer uttalelsen, og sier seg enig i forståelsen i sin uttalelse 25. august 2008. I den aktuelle saken ga Sivilombudsmannen uttrykk for at skattyter ikke burde få dekket sine kostnader, ettersom han hadde vært for tilbakeholden med å gi opplysninger om faktum. ${ }^{141}$

Tilbake står de tilfeller der ligningsmyndighetene på bakgrunn av de samme faktiske opplysninger og de samme rettslige regler og vurderinger rett og slett har ombestemt seg. Etter det jeg kan se, berører Finansdepartementet denne problemstillingen i sitt brev 6. juli 2007: "Der nemnda endrer skjønnsutøvelsen til skattyters gunst, er det ikke like klart at det vil være urimelig om skattyter dekker sakskostnadene selv. Her kan man ikke på samme måte som [ved rettslige vurderinger] si at ligningsforvaltningen har begått en feil.” I svarbrev til Sivilombudsmannen 24. oktober $2007^{142}$ henviser Finansdepartementet til at det ifølge Ot.prp. nr. 29 (1978-1979) side 120-121 "må foreligge en ekstraordinær situasjon for at "urimelighetsvilkåret" i ligningsloven § 9-11" er oppfylt. Departementet henviser videre til ovennevnte brev av 6. juli 2007, hvor det sies: "Dette kan tyde på at det skal en del til før det vil være urimelig om en skattyter må dekke sakskostnader selv”. Men departementet presiserer at det også kan tilkjennes kostnadsdekning når skjønnsutøvelsen endres til skattyters gunst. Jeg vil også nevne at Lignings-ABC fra og med utgaven for 2007/08 gir uttrykk for dette synet. ${ }^{143}$ Departementet uttrykker klart at § 9-11 gir hjemmel for kostnadsdekning ved endring av skjønnsmessige avgjørelser, men det gis ingen ytterligere beskrivelse av noen slik "ekstraordinær situasjon" i tilfeller hvor det ikke foreligger feil eller klanderverdige forhold.

\footnotetext{
${ }^{141}$ Sak 2007/956.

${ }^{142}$ Sak 2007/956.

${ }^{143}$ Punkt 2.2.4 på side 381.
} 
Gulating lagmannsrett mente i dom 16. mars 2005 at satsen for tilleggsskatt burde halveres, fordi det forelå delvis unnskyldelige forhold ( $§ 10-4$ nr. 2, jf. § 10-3 bokstav b). Selv om retten ikke kommer med konkrete utsagn, tolker jeg retten slik at den regner dette som en del av rettsanvendelsen hvor det foreligger dekningsrett. ${ }^{144}$

Østfold fylkesskattenemnd tilkjente i sak fra SFS full dekning for de sakskostnader som var knyttet til det forhold at tilleggsskatten fullt ut var frafalt. Nemnda fant at det ville være urimelig om skattyter selv måtte dekke kostnadene ved å få punktet endret, ettersom endringen gjaldt rettsanvendelsen. ${ }^{145}$

I sak 2001-408OLN fra overligningsnemnda for SFS ble det derimot nektet dekning fordi saken gjaldt "en kompleks problemstilling med skjønnsmessige vurderinger". Nemndas uttaler også at "spørsmålet ikke var klart" og at nemndas konklusjon var "basert på en konkret helhetsvurdering med et noe annerledes resultat enn ligningsnemnda". ${ }^{146}$

Overligningsnemnda for SFS uttalte i sak 2000-403OLN at det ikke var uenighet "om tolkningen av en lovbestemmelse", at avgjørelsen "er fattet etter en ganske fri avveining av en rekke momenter" og "man kan vanskelig si at den ene løsningen er vesentlig mer riktig enn en annen”. Nemnda mente at det på et slikt grunnlag ikke var urimelig at skattyter selv måtte dekke kostnadene. ${ }^{147}$

Til slutt vil jeg nevne Østfold fylkesskattenemnds uttalelser i sak fra SFS. Den er klaget inn for Sivilombudsmannen, men som nevnt ovenfor anviste han en løsning på annet grunnlag. ${ }^{148} \mathrm{Ut}$ fra min problemstilling er nemndas uttalelser likevel interessante. I referatet sies det at "fylkesskattenemnda antok at det ikke på generelt grunnlag var holdepunkter for å unnta verdsettelsesskjønn fra sakskostnadsdekningen”. Nemnda uttalte likevel at "det ved

\footnotetext{
${ }^{144}$ Utv. 2005 side 741, se også Lovdata med referanse LG-2003-6419.

${ }_{145}$ Utv. 2007 side 244. Referert under punkt 3.2.13.

146 Almvik og Kristiansen (2006), sitat og omtale på side 1086.

${ }_{147}$ Almvik og Kristiansen (2006), sitat og omtale på sidene 1085-6.

${ }^{148}$ Sak $2007 / 956$.
} 
kompliserte skjønnsfastsettelser ville være grunn til å vise tilbakeholdenhet med å tilkjenne sakskostnader". Deretter uttalte nemnda at den fant holdepunkter i forarbeidene for at kostnadsdekningen burde avgrenses mot tilfeller hvor "endringen i skattyters favør bare gjelder utøvelsen av fritt skjønn innenfor rettsreglenes grenser". Nemnda fant det derfor ikke urimelig at skattyter dekket sine kostnader selv. ${ }^{149}$

Etter det jeg kan se, blir de skjønnsmessige avgjørelsene som er mer lovbundne, i praksis henført til rettsanvendelsen hvor det utvilsomt foreligger dekningsrett. Imidlertid ser jeg ikke eksempler på at man i praksis har dekket kostnader i tilfeller hvor skjønnet har vært mer fritt. Det er heller ingen entydig definisjon av begrepene "fritt" og "lovbundet" skjønn verken i teori eller praksis, ${ }^{150}$ slik at også denne vurderingen innebærer ut øvelse av et visst skjønn. Videre er det uklart hva som skal til for å statuere dekningsrett når det er en mer fri skjønnsmessig vurdering som er endret. Jeg konstaterer at rettstilstanden er usikker. I motsetning til dette gir $§ 36$ utvilsomt dekningsadgang ved endring av alle typer skjønnsmessige avgjørelser.

\subsection{Sammenlikning}

I de foregående avsnittene har jeg løpende trukket en del paralleller mellom de enkelte delene av regelverket i $\S 9-11$ og $\S 36$. Her vil jeg foreta en mer overordnet sammenlikning.

Finansdepartementet uttalte i Ot.prp. nr. 29 (1978-1979) side 120 at ligningsforvaltningen skilte seg så mye ut fra øvrig forvaltning av det var "lite hensiktsmessig å ta utgangspunkt i forvaltningsloven $\S 36$ første ledd og ta den opp i utkastet til ligningslov med bestemte tilpasninger." Men etter min gjennomgang må jeg konstatere at likhetene er større enn ulikhetene. Rett nok har reglene motsatt utgangspunkt. Etter $\S 36$ "skal" det $\mathrm{i}$ utgangspunktet dekkes kostnader, mens det etter § 9-11 nr. 4 'bare skal' dekkes kostnader

\footnotetext{
${ }_{149}$ Utv. 2007 side 244. Referert under punkt 3.2.13.

150 Se Eckhoff (Smith 2003), side 337-340.
} 
hvis flere kriterier er oppfylt. Men begge regler gir anvisning på justeringer i dekningsretten som gjør at sluttresultatet etter min mening ikke er så ulikt.

De grunnleggende kravene er nokså like. Utgangspunktet etter begge regler er at det har blitt fattet et nytt vedtak i saken, som i det minste må være delvis til gunst for den private parten. Kravet om årsakssammenheng følger som nevnt av ordlyden i § 36 (se avsnitt 3.1.3.2). Det innfortolkes som en del av § 9-11, først og fremst i vesentlighetskriteriet (se avsnitt 3.2.2.1). Til sammen omfatter vesentlighetskriteriet og kriteriet om "god grunn" (se avsnitt 3.2.2.2) etter § 9-11 stort sett det som følger av nødvendighetskriteriet (se avsnitt 3.1.3) etter $\S 36$.

Jeg ser også at det skal foretas en rimelighetsvurdering etter begge regler, men med motsatt fortegn (se avsnitt 3.1.4 og 3.2.3). Innholdsmessig er den stort sett lik, og jeg ser kun ett prinsipielt viktig unntak. Etter $§ 36$ er kostnader vedrørende frie skjønnsmessige vurderinger utvilsomt omfattet av dekningsretten. Etter § 9-11 kan man ikke si at rettstilstanden er klar når det gjelder de tilfellene hvor ligningsmyndighetene rett og slett har ombestemt seg (se avsnitt 3.2.3.5).

Praktiseringen av reglene har fått lov til å utvikle seg svært ulikt over mange år. Gjennomgangen under avsnitt 3.1 viser at det slett ikke er slik at det alltid dekkes fulle kostnader etter $\S 36$ i merverdiavgiftssakene, men at dekningen svært ofte reduseres etter en svært konkret gjennomgang med henvisning til nødvendighetskriteriet. Avgjørelsene i merverdiavgiftssakene framstår generelt som mindre formalistiske. De virker mer rettet inn mot å skille ut de dekningsberettigede, 'nødvendige' sakskostnadene. Klagenemndas praksis virker også å være svært entydig, og jeg ser at det ofte henvises til tidligere saker både fra forvaltningens og fra skattyters side.

Dette står i sterk kontrast til ligningsavgjørelsene. Av den praksis jeg viser til i avsnitt 3.2 framgår det tydelig at § 9-11 på flere punkter har blitt praktisert forskjellig gjennom flere år. Dette på tross av at generelle retningslinjer sannsynligvis har vært lettere tilgjengelig for 
forvaltningen via anvisninger i Lignings-ABC og Utvalget (se avsnitt 1.3). Og den praksis som er tilgjengelig skulle også vise at dekningskravene ofte er avvist etter vurdering av lovens formelle kriterier.

På disse to områdene har det tydeligvis utviklet seg to forskjellige forvaltningstradisjoner, som gir seg utslag i klare forskjeller i praktiseringen. Etter min mening er praksis langt mer forskjellig enn det lovbestemmelsene i seg selv skulle tilsi. Den private part som har søkt bistand hos advokat både for sin merverdiavgiftssak og sin skattesak har ingen grunn til å finne det logisk at de to sakene er løst på helt forskjellig vis.

Under avsnitt 1.2 har jeg vist til at ligningsforvaltningen og merverdiavgiftsforvaltningen stiller mange av de samme krav til den private partens opplysnings- og samarbeidsplikt. Imidlertid er ligningsforvaltningen på sin side ikke stilt overfor så strenge plikter til utredning og informasjon som det merverdiavgiftsforvaltningen er (se avsnitt 2.4). Min gjennomgang av gjeldende rett har vist at praksis i sakskostnadssakene avviker i større grad enn nødvendig. Når jeg sammenholder disse momentene kan jeg ikke se at det finnes noen god begrunnelse for de forskjellene som finnes per i dag. 


\section{De lege ferenda: Bør forvaltningsloven $\S 36$ brukes i alle skatteetatens saker?}

Jeg vil først knytte noen kommentarer til dagens bestemmelser i § 9-11 med tilhørende regelverk.

Ved første øyekast kan det faktisk se ut som om § 9-11 virkelig ble endret i samsvar med hovedregelen i § 36 da den ble omredigert ved lov 15. desember 2006 nr. 77. Etter nåværende ordlyd står det i § 9-11 nr. 1 at skattekontoret "skal ... tilkjenne skattyteren hel eller delvis dekning". Av nr. 1 framgår ikke noen andre kriterier for dekning enn at ligningsavgjørelse må være endret til gunst for skattyteren. Etter en overfladisk sammenligning med § 36 kan det derfor virke som om § 9-11 har tilnærmet samme utgangspunkt, nemlig en presumsjon for dekning av sakskostnader.

Når en leser videre i § 9-11, blir det etter hvert klart at lovens hovedregel er den samme som før, nemlig at ikke skal tilkjennes dekning. Kriteriene for dekning står i § 9-11 nr. 4, og er ganske snevre. Fortsatt må alle de tre kriteriene være oppfylt.

Loven er nå redigert på en måte som gjør at den er lett å misforstå. § 9-11 var fra starten av ment å skulle ha regler som svært bevisst skulle avvike sterkt fra $\S 36$. Dette framgår slett ikke så tydelig lenger av den omredigerte ordlyden.

Uttrykket "skal" i bestemmelsens nr. 1 er direkte misvisende. Språklig sett vil uttrykket henlede oppmerksomheten på en plikt eller rett. I den sammenhengen det står i bestemmelsen, kan jeg ikke se at det egentlig har noen selvstendig betydning. Det har bare mening som en del av uttrykket "skal [ ] tilkjenne skattyteren hel eller delvis dekning". Rent logisk følger også dette som den siste vurderingen som skal foretas etter at de tre 
kumulative kriteriene etter nr. 4 er vurdert. Hvis disse ikke er oppfylt, er det nemlig intet å vurdere hel eller delvis dekning for.

Isolert sett er også systematikken i loven dårlig. Begge de svært snevre unntaksbestemmelsene i nr. 2 og nr. 3 kommer systematisk før det som er lovens hovedregel. Den framgår etter en sammenstilling av bestemmelsene i nr. 1 og nr. 4, eller unntaksvis av nr. 2. eller nr. 3. sammenholdt med nr. 4. Av nr. 5 framgår både reglene for den mest praktiske klagerunden til skatteklagenemnda og en del andre saksbehandlingsregler.

Det hadde lettet oversikten vesentlig hvis lovens hovedregel med de grunnleggende kriteriene hadde framgått av lovens nr. 1. Deretter kunne man ha angitt de mest praktiske klagereglene og deretter de mer snevre anvendelsesområdene.

Ved endringslov 27. mai 1977 nr. 40 ble det i § 36 (nåværende fjerde ledd) lovfestet en plikt til å varsle skattyteren om retten til å kreve dekning for sakskostnader. Det er etter mitt skjønn betenkelig at det ikke er lovfestet en tilsvarende plikt i ligningsloven. Instruks av 26. januar $1984 \mathrm{nr}$. 17 om underretning til skattyteren om adgang til å få dekket sakskostnader pålegger klart nok ligningsforvaltningen å varsle, men regulerer etter min mening ikke skattyters rett til å motta slik informasjon godt nok.

Etter mitt skjønn er det også betenkelig at de veiledende retningslinjene av 26. januar 1984 nr. 16 om adgangen til å få dekket sakskostnader ennå ikke er avløst av regler som gir en mer forpliktende anvisning på praktiseringen. Det er betegnende at det raskt etter at retningslinjene ble gitt, oppsto tvil om deres formelle status. Finansdepartementet uttalte i 1985 at retningslinjene først og fremst er ment for internt bruk i Skatteetaten. ${ }^{151}$ I de årene som har gått siden da, har nok hensynet til at skattyterne skal kunne forutberegne sin rettsstilling fătt større fotfeste (se avsnitt 2.4). I et slikt lys finner jeg det betenkelig at det

\footnotetext{
${ }^{151}$ Se Finansdepartementets presisering i brev 28. november 1985, inntatt i Utv. 1985, side 684.
} 
fortsatt ikke er gitt bindende retningslinjer, eksempelvis i form av forskrifter, som kan tjene til veiledning for skattyter.

Så langt må jeg konkludere med at det er på høy tid at § 9-11 med tilhørende regelverk vurderes nærmere.

Videre er spørsmålet om regelen rett og slett bør oppheves, eventuelt endres til kun å henvise til behandling i samsvar med forvaltningsloven $\S 36$.

Finansdepartementet henviser i brev 6. juli 2007 at "rettsutviklingen på området" må tas i betraktning. ${ }^{52}$ Selv om en ved rettens utsagn kan få avklart enkelte spørsmål, vil det etter mitt skjønn være vanskelig å frigjøre regelen helt fra de tydelige intensjonene i forarbeidene. § 9-11 har som vist i avsnitt 2.4 en uheldig binding til § 36 slik den $1 \varnothing \mathrm{d}$ før lovendring 12. januar 1995 nr. 4. For å gjøre § 9-11 til en fleksibel regel innenfor dagens ligningsforvaltning, er det behov for en gjennomgående revisjon med gode forarbeider som en gang for alle bryter forbindelsen med fortiden.

For forvaltningsloven $\S 36$ er situasjonen stikk motsatt. Som vist under avsnitt $2.2 \mathrm{er}$ det smått med forarbeider, og gjennomgangen under avsnitt 3.1 har tydelig vist at regelen er svært anvendelig i merverdiavgiftssakene. Denne regelen var ifølge uttalelsene fra Justiskomiteen i Innst.O. nr. 4 (1994-1995) side 10 også ment å være fleksibel (se avsnitt 2.2). Særregler vedrørende merverdiavgiftssakene er inntatt i forvaltningsforskriften. ${ }^{153}$

I stedet for å foreta en fullstendig revisjon av § 9-11 finnes det etter min mening en langt enklere løsning. § 36 har gjennom en årrekke vist seg å være en svært anvendelig regel for merverdiavgiftssakene. Jeg ser ingen grunn til at $§ 36$ skulle være mindre anvendelig for skattesakene.

\footnotetext{
${ }^{152}$ Utv. 2007 side 1266.

${ }^{153}$ Forskrift 15. desember 2006 nr. 1456.
} 


\section{Konklusjon}

Etter min mening er tiden inne til å ta et oppgjør med forestillinger som har fått stå urørt i lang tid.

Det er tydelig at tiden har løpt fra forestillingen om ligningsforvaltningens særstilling som betinger strenge unntaksregler motivert ut fra effektivitetshensyn.

Reglene har blitt praktisert svært forskjellig over lang tid. Både fra forvaltningens og fra den private parts synsvinkel må det kunne sies å ha vært uheldig.

Ved å føre behandlingen av ligningsavgjørelsene over i den generelle forvaltningsretten tror jeg det for framtiden vil være lettere å unngå uheldige avvik. Ligningslovens regel er på en uheldig måte koblet opp til en foreldet rettstilstand, og det har i praksis vist seg vanskelig å tilpasse regelen til en endret virkelighet. Forvaltningslovens regel har vist seg å være mer tilpasningsdyktig, noe som er nødvendig for et samfunn i endring.

Merverdiavgiftspraksis viser tydelig at forvaltningslovens regel er langt lettere å praktisere.

Og det er heller ikke store prinsipielle forskjeller i dekningsretten mellom de to reglene. Derfor burde det ikke ha store ressursmessige konsekvenser for forvaltningen at skattesakene behandles etter $\S 36$. Effektivitetshensynet kan også ivaretas ved at avgjørelsene blir mindre formalistiske og omfangsrike, og at avgjørelsene blir enklere å treffe. Og en bør vente at hensynet til rettferdighet skattyterne imellom og hensynet til at skattyterne kan forutberegne sin rettsstilling blir bedre ivaretatt. Oppmerksomheten kan da konsentreres om det som burde være hovedformålet bak dekningsreglene - nemlig at de nødvendige kostnadene blir dekket. 
Min hovedkonklusjon må bli at steget bør tas fullt ut. Både for forvaltningen og for den private part vil dette etter mitt syn være den beste løsningen. Sakskostnadssakene for ligningsavgjørelser bør derfor behandles etter forvaltningslovens generelle regel i § 36 . 


\section{Litteraturliste}

6.1 Oversikt over forvaltningsoven med tilhørende relevante forarbeider, forskrifter og rundskriv m.v.

Lov om behandlingsmåten i forvaltningssaker (forvaltningsloven) av 10. februar 1967.

\subsubsection{Relevante forarbeider til forvaltningsloven i kronologisk rekkefølge}

Ot.prp. nr. 38 (1964-1965). Om lov om behandlingsmåten i forvaltningssaker (forvaltningsloven).

Ot.prp. nr. 27 (1968-1969) Ikraftsettelse av forvaltningsloven og om endringer av saksbehandlingsregler i forvaltningsloven og andre lover.

Innst.O. XXII (1968-1969) Innstilling fra justiskomiteen om lov om ikrafttredelse av forvaltningsloven og om endringer av saksbehandlingsregler i forvaltningsloven og andre lover.

Ot.prp. nr. 3 (1976-77) Om lov om endringer i lov 10 februar 1967 om behandlingsmåten i forvaltningssaker (regler om taushetsplikt m. m.)

Innst.O. nr. 50 (1976-77) Innstilling fra justiskomiteen om lov om endringer i lov 10. februar 1967 om behandlingsmåten i forvaltningssaker (Regler om taushetsplikt m.m.).

Ot.prp. nr. 75 (1993-1994) Om lov om endringer i forvaltningsloven m v

Innst.O. nr. 4 (1994-1995) Innstilling fra justiskomiteen om lov om endringer i forvaltningsloven m.v. 


\subsubsection{Forskrift til forvaltningsloven}

Forskrift til forvaltningsloven (forvaltningslovforskriften) av 15. desember 2006 nr. 1456.

\subsubsection{Rundskriv vedrørende forvaltningsloven}

Rundskriv G-37/95 fra Justis- og politidepartementet om endringer i forvaltningsloven m.v. av 23. mars 1995 (saksnummer 1995/694 E). 
6.2 Oversikt over Ligningsloven med tilhørende relevante forarbeider, forskrifter og rundskriv m.v.

\subsubsection{Ligningsloven}

Lov om ligningsforvaltning (ligningsloven) av 13. juni $1980 \mathrm{nr} .24$.

\subsubsection{Relevante forarbeider til ligningsloven}

Innst. III om ligningsforvaltning fra Likningsforvaltningsutvalget av 1961.

Ot.prp. nr. 29 (1978-1979). Ligningslov og endringer i andre lover.

Innst.O. nr. 44 (1979-1980). Innstilling fra finanskomiteen om ligningslov og endringer i andre lover.

Ot.prp. nr. 21 (1991-1992). Endringer i skatteloven m.fl.

Innst.O. nr. 46 (1991-1992). Innstilling frå finanskomiteen om endringar i skattelova m.fl.

Ot.prp. nr. 1 (2006-2007). Skatte- og avgiftsopplegget 2007 - lovendringer.

Innst.O. nr. 10 (2006-2007). Innstilling frå finanskomiteen om skatte- og avgiftsopplegget 2007 - lovendringar.

\subsubsection{Relevante forskrifter til ligningsloven}

Forskrift om overgangsbestemmelser ved iverksettelse av ny organisering av ligningsmyndighetene 1. januar 2008 av 16. november 2007 nr. 1258.

Forskrift om når skatteklagenemndas vedtak kan bringes inn for overprøving i Riksskattenemnda av 23. november 2007 nr. 1285. 


\subsubsection{Relevante instrukser og retningslinjer til ligningsloven}

Finansdepartementets veiledende retningslinjer om adgangen til å få dekket sakskostnader (forkortet: Retningslinjer) av 26. januar 1984 nr. 16.

Finansdepartementets instruks om underretning til skattyteren om adgang til å få dekket sakskostnader av 26. januar 1984 nr. 17. 


\subsection{Andre lover}

Lovene er oppstilt i kronologisk orden

1911 Lov om skatt av formue og inntekt (skatteloven) av 18. august $1911 \mathrm{nr}$. 8. Lovens tittel før 1. januar 1976: Skattelov for landet. Opphevet 1. januar 2000 ved lov 26. mars 1999 nr. 14.

1911 Skattelov for byene av 18. august $1911 \mathrm{nr}$. 9. Opphevet og slått sammen med lov av 18. august $1911 \mathrm{nr} .8$ ved lov av 14. mars 1975 nr. 5.

1915 Lov om rettergangsmåten for tvistemål (tvistemålsloven) av 13. august 1915 nr. 6. Opphevet 1. januar 2008 ved lov 17. juni 2005 nr. 90.

1962 Lov om Stortingets ombudsmann for forvaltningen (sivilombudsmannsloven) av 22. juni $1962 \mathrm{nr} .8$.

1966 Lov om folketrygd (folketrygdloven) av 17. juni $1966 \mathrm{nr}$. 12. Opphevet 1. mai 1997 ved lov 28. februar $1997 \mathrm{nr} .19$.

1969 Lov om merverdiavgift (merverdiavgiftsloven) av 19.06 .1969 nr. 66.

1980 Lov om fri rettshjelp (rettshjelploven) av 13. juni 1980 nr. 35.

1997 Lov om folketrygd (folketrygdloven) av 28. februar $1997 \mathrm{nr}$. 19. I kraft 1. mai 1997.

1999 Lov om skatt av formue og inntekt (skatteloven) av 26. mars 1999 nr. 14.

2005 Lov om mekling og rettergang i sivile tvister (tvisteloven) av 17. juni 2005 nr. 90. I kraft 1. januar 2008 ifølge resolusjon 26. januar 2007 nr. 88. 


\subsection{Bøker, tidsskrifter og henvisninger til internett}

Avgiftsnytt. Utgis av Skattebetalerforeningen i 6 årlige hefter.

Bedriftsbeskatning i praksis. Redigert av Petter Chr. Wilskow. 1. utgave. Oslo, 1997.

Bedriftsbeskatning i praksis 2000. Redigert av Fred-Ove Almvik, Vegard Kristiansen og Anders Myklebust. 2. utgave. Oslo, 2000.

Bedriftsbeskatning i praksis. Redigert av Fred-Ove Almvik og Vegard Kristiansen. 3. utgave. Oslo, 2006.

Bernt, Jan Fridthjof. Kommentarer til forvaltningsloven. Rettsdata-skatterett: Gyldendal rettsdata http://www.rettsdata.no (betaltjenesten spesialfag - skatterett) [sitert 1. november 2008].

Eckhoff, Torstein og Jan E. Helgesen. Rettskildelære. 5. utgave, revidert av Jan E. Helgesen Oslo, 2001.

Eckhoff, Torstein og Eivind Smith. Forvaltningsrett. 7. utgave, revidert av Eivind Smith. Oslo, 2003.

Frihagen, Arvid. Forvaltningsrett II. 4. reviderte utgave. Bergen, 1981.

Harboe, Einar, Truls Leikvang og Rino S. Lystad. Ligningsloven med kommentarer. 6. utgave. Oslo, 2005.

Lignings-ABC 2007/08. Utarbeidet av Skattedirektoratet. 29. utgave. Oslo, 2008. 
Lovavdelingens uttalelser (1976-1988). Redigert av Wilhelm Matheson og Geir Woxholth. Oslo, 1990.

Lovdata. http://www.lovdata.no (betalsystemet Lovdata online) [sitert 1. november 2008].

Merverdiavgiftshåndboken. Utarbeidet av Skattedirektoratet. 5. utgave, Oslo, 2007.

Utvalget. Dommer, uttalelser m.v. i skattesaker. Utgis av Ligningsutvalget i 10 årlige hefter (vanligvis forkortet Utvalget eller Utv.)

Woxholt, Geir. Forvaltningsloven med kommentarer. 4. utgave. Oslo, 2006.

Zimmer, Frederik og Knut Erik Omholt. Ligningsforvaltningsrett. 3. utgave. Oslo, 1993. 


\subsection{Register over dommer}

For Høyesteretts dommer er det henvist til Norsk Retstidende (Rt.), for øvrige dommer fortrinnsvis til Lovdatas referanse. Ellers er det henvist til referat gjengitt i Utvalget.

LB-1998-674

LB-2003-9932

LB-2006-132699

LF-1995-72

LG-2003-6419

Rt. 2000 side 268

Rt. 2005 side 692

TOSLO-2001-4697

TOSLO-2003-12153

Utv. 1987 side 267 (referat fra dom i Bergen byrett)

Utv. 1988 side 684 (referat fra dom i Gulating lagmannsrett)

Utv. 1992 side 548 (referat fra dom i Frostating lagmannsrett) 
6.6 Register over saker fra Klagenemnda for merverdiavgift

Henvisninger til Lovdatas referanse.

KMVA-2001-4295

KMVA-2002-3927

KMVA-2002-4573b

KMVA-2002-4790b

KMVA-2004-3998b

KMVA-2004-4833a

KMVA-2004-4930a

KMVA-2004-4933b

KMVA-2004-4981

KMVA-2004-5123b

KMVA-2005-5214b

KMVA-2005-5235b

KMVA-2006-5323b

KMVA-2006-5472

KMVA-2007-4716bb

KMVA-2008-6111 


\subsection{Register over Sivilombudsmannens uttalelser}

Henvisninger fortrinnsvis til Lovdatas referanse. Ellers til Sivilombudsmannens saksnummer.

Somb-1981-67

Somb-1999-84

Somb-1999-85

Sombu-2000-5

Somb-2000-50

Somb-2000-53

Somb-2004-61

Somb-2006-63

Somb-2006-66

Sak 2007/956 